NBER WORKING PAPER SERIES

\title{
REMITTANCE RESPONSES TO TEMPORARY DISCOUNTS: A FIELD EXPERIMENT AMONG CENTRAL AMERICAN MIGRANTS
}

\author{
Kate Ambler \\ Diego Aycinena \\ Dean Yang \\ Working Paper 20522 \\ http://www.nber.org/papers/w20522
}

\author{
NATIONAL BUREAU OF ECONOMIC RESEARCH \\ 1050 Massachusetts Avenue \\ Cambridge, MA 02138 \\ September 2014
}

\begin{abstract}
Kevin Carney, our Innovations for Poverty Action project associate, deserves special thanks for superb work on all aspects of project implementation and data management. This project would not have been possible without the collaboration of Viamericas Corporation and their participating agents. We greatly appreciate the support and feedback of Luis Alejos Marroquín, Paul Dwyer, Daniel Gottschalk, Gabriela Inchauste, Yusufcan Masatlioglu, Celia Medrano, Carlos Sarmiento, and seminar participants at IFPRI, the 11th Midwest International Economic Development Conference, the 8th Annual Meeting of the Impact Evaluation Network, and the 7th International Conference on Migration and Development (Oxford). This study was funded by the Inter-American Development Bank (contract C0016-11) and by the University of Michigan's Population Studies Center. Ambler is grateful for the support of an NICHD training grant to the Population Studies Center at the University of Michigan (T32 HD007339). The views expressed herein are those of the authors and do not necessarily reflect the views of the National Bureau of Economic Research.
\end{abstract}

NBER working papers are circulated for discussion and comment purposes. They have not been peerreviewed or been subject to the review by the NBER Board of Directors that accompanies official NBER publications.

(C) 2014 by Kate Ambler, Diego Aycinena, and Dean Yang. All rights reserved. Short sections of text, not to exceed two paragraphs, may be quoted without explicit permission provided that full credit, including $\odot$ notice, is given to the source. 
Remittance Responses to Temporary Discounts: A Field Experiment among Central American Migrants

Kate Ambler, Diego Aycinena, and Dean Yang

NBER Working Paper No. 20522

September 2014

JEL No. F24,J61,O15

\begin{abstract}
We study the impacts on remittances of offering migrants temporary discounts on remittance transaction fees. We randomly assigned migrants from El Salvador and Guatemala 10-week remittance transaction fee discounts, and assess impacts using administrative transaction data and a post-experiment survey. Temporary discounts lead to substantial increases in the number of transactions and total amount remitted during the discount period. Surprisingly, these increases persist up to 20 weeks after expiration of the discount. We find no evidence that the discounts cause migrants to shift remittances from other remittance channels, or to send remittances on behalf of other migrants. These findings are consistent with naïveté on the part of migrants regarding remittance recipients' reference-dependent preferences.
\end{abstract}

Kate Ambler

International Food Policy Research Institute $2033 \mathrm{~K} \mathrm{St}, \mathrm{NW}$

Washington, DC 20006

k.ambler@cgiar.org

Diego Aycinena

Universidad Francisco Marroquín

6a calle final zona 10

Edificio Académico, Oficina E-503

Ciudad de Guatemala

Guatemala

diegoaa@ufm.edu
Dean Yang

University of Michigan

Department of Economics and

Gerald R. Ford School of Public Policy

735 S. State Street, Room 3316

Ann Arbor, MI 48109

and NBER

deanyang@umich.edu 


\section{Introduction}

International remittances sent to the developing world have become an important focus of development policy over the last two decades. ${ }^{1}$ Remittances to developing countries amounted to \$401 billion in 2012, a number that far exceeded official development assistance (World Bank 2013). The interest in remittances has also been driven by a growing number of studies that document positive impacts of remittances on a number of measures of well-being in recipient households, including education, health, housing, poverty, entrepreneurship, and responsiveness to negative shocks (Ambler et al. forthcoming; Cox-Edwards and Ureta 2003; Adams 2004; Yang and Martinez 2005; Yang 2006; Woodruff and Zenteno 2007; Yang and Choi 2007; Yang 2008a; Yang 2008b; Adams and Cuecuecha 2010; Theoharides 2013). This research suggests that further increasing remittances could play an important role in achieving development goals.

Despite this policy interest in increasing remittances, much less is known about how migrants make decisions about the remittances they send. In this paper we study an important component of every remittance sent through the formal financial system: the fee charged by the money transmission institution for the service they provide, the reduction of which is a common policy recommendation. ${ }^{2}$ Remittance fees are generally charged as a flat fee up to a certain amount. In our context of Central Americans remitting from the United States, some of the lowest fee corridors, these fees are usually $\$ 8$ to $\$ 10$ for remittances up to $\$ 1,000$ or $\$ 1,500$, but the costs can vary widely by market. Fees can therefore represent a high percentage of the overall remittance, especially for migrants sending smaller amounts. Understanding how these fees impact decisions is important for the design of policies that seek to lower them. For example, migrants could keep any fee reduction for themselves, or they could add it to the remittance they send home, resulting in minimal increases in remittances at most. Alternatively, behavioral models allow for situations where discounts may have large and persistent impacts on total remittances. However, very little research exists investigating how exactly remittance fees impact the decisions that migrants make about remittances. ${ }^{3}$

\footnotetext{
${ }^{1}$ See Pew Hispanic Center (2002), Terry and Wilson (2005), World Bank (2006), and World Bank (2007) for examples of policy oriented reports.

2 See, among others, de Luna Martinez (2005), Frias (2004), Orozco (2002), Orozco and Wilson (2005), Orozco and Fedewa (2006), Pew Hispanic Center (2002), Ratha (2005), Ratha and Riesberg (2005) World Bank (2006), World Bank (2007), and World Bank (2013).

${ }^{3}$ Clemens and Ogden (2013) identify the cost of remittances (in the form of subsidies or taxes) as one of the most important areas in research into remittances and development.
} 
Three existing studies address the impact of the cost of remittances on remittance flows. Freund and Spatafora (2006) use cross-country data to show that remittance fees are negatively correlated with total remittances at the country level. Gibson, McKenzie, and Rohorua (2006) find that, in response to a hypothetical survey question, migrants report that they would send more in remittances if fees were lowered. These studies provide initial evidence that remittance fees are an important determinant in remittance decisions, but have some important shortcomings. Cross country regressions may suffer from omitted variable bias and reverse causality, and while hypothetical evidence is suggestive, it is not clear how well the hypothetical responses will correlate with actual remittance decisions.

Aycinena, Martinez, and Yang (2010) provide field experimental evidence on the impact of remittance fees on remittances. They randomly assign Salvadoran migrants discounts on remittance fees at a partner institution. The randomized experiment allows for the causal identification of the impact of the remittance prices, and, importantly, the paper measures actual, as opposed to hypothetical, remittance flows. They find that a $\$ 1$ reduction in the price of a remittance leads to a \$25 monthly increase in remittance payments. However, the study has certain limitations. Most participants were not baseline customers of the partner institution, limiting the ability to observe full remittance behavior and raising concerns that the effects might be driven by switching remittance companies or sending remittances for others. Additionally, data is not available for the period after the discounts expired, so the authors cannot observe longer term effects on remittance behavior after discount expiration. Because the impacts of the randomized price are large and carry important policy implications, it is important to verify these results in a setting where these limitations are addressed.

This paper reports the results of a randomized experiment designed to measure the causal impact on remittances of temporary discounts on remittance fees. We partner with a money transfer company (Viamericas Corporation) and recruit migrants from El Salvador and Guatemala to participate at their agent locations. All participants are existing customers of Viamericas at baseline. Half of the participating migrants are randomly chosen to receive a \$3.01 discount for 10 weeks for remittances sent at that Viamericas location. The discount is limited to remittances sent to the person previously identified by the migrant as their primary remittance recipient (PRR). This restriction is designed to reduce the probability that migrants will use the discount to send remittances for others, thereby artificially increasing the amount of remittances sent. As part of a 
larger project addressing the impact of remittances on education, half of the migrants are also randomly allocated to receive information on returns to schooling in their home country.

We then examine impacts of these treatments by looking at remittance transactions and amounts in Viamericas administrative data, a data source that reduces measurement error in the remittance data. We have access to the transaction data for participants before, during, and after the discount period allowing us to examine the longer term impacts of these price discounts. This transaction data is complemented with an endline survey that provides insight into use of other remittance channels and asks participants whether they used the discount to remit for others.

We find that, during the 10 -week discount validity period, the discount has a statistically significant positive impact on the number of separate remittance transactions made by study participants. This effect is large in magnitude, amounting to 0.56 additional remittances, or a 19.0\% increase over the 3.44 remittances sent by the control group during the same 10-week period. There is no large or statistically significant impact on the dollar amount transferred per remittance, so the discount has a positive and statistically significant impact on the total money amount of remittances as well, specified as the inverse hyperbolic sine transformation (IHST) of total dollars sent. ${ }^{4}$

A discount-induced increase in the number of remittance transactions and in the total remittances by value during the discount period is not surprising in itself, and might simply be due to migrants inter-temporally shifting a planned later remittance transaction to occur earlier, so as to take advantage of the discount. If this were the case, we would expect to see a corresponding reduction in remittance transactions and total remittance amounts after the expiration of the discount. This would show up in the analysis as negative treatment effects on these dependent variables, in magnitudes similar to those found during the discount period (in absolute value).

As it turns out, this is not the case. We find that treatment effects on number of remittance transactions and on the IHST of the total value of remittances remain positive in periods after discount expiration. Effects are large in magnitude and statistically significantly different from zero up to 20 weeks after discount expiration (up to twice the length of the original discount period). ${ }^{5}$

\footnotetext{
${ }^{4}$ Estimated impacts on the $\log (1+$ dollars sent in remittances $)$ are very similar. Impacts on dollars of remittances sent are also positive, but are quite imprecise due to the presence of large outliers.

${ }^{5}$ The education information treatment has no impact on remittance behavior.
} 
Additional analyses indicate that these results represent true increases in remittances. The increases are concentrated among remittances sent to the primary remittance recipient, but these increases are much larger than any reductions in remittances sent to other recipients. Migrants are existing Viamericas customers and report minimal remittances sent through other channels both at baseline and endline. Importantly, there is no impact of the treatment on remittances sent through other channels reported in the endline survey. Finally, questions in the endline survey designed to address the concern that migrants might send remittances for others in order to take advantage of the discount show no consistent pattern related to treatment that might be driving the results.

These large and persistent effects of the discount treatment are puzzling when viewed through the lens of standard economic models. However, they are consistent with behavioral models with reference dependence and status quo bias, such as Tversky and Kahneman (1991), Masatlioglu and Ok (2005), and Masatlioglu and Ok (2014). We discuss our results in light of these models in our conclusion.

\section{Project design}

Given the difficulty of identifying the causal effect of remittance prices on remittance behavior using observational or hypothetical data, we work with a money transfer company and randomly assign price discounts to some of their customers. The random assignment of discounts allows us to causally identify the impact of lower prices on remittance behavior. We partner with Viamericas Corporation, an international money transfer company that provides remittance sending services from the United States to a large number of countries across the world with a concentration in the Latin American and Caribbean market. Fees vary across markets, but the cost of sending a remittance less than $\$ 1,000$ from the Washington, DC area is generally a flat fee of \$8. ${ }^{6}$ Although Viamericas offers online and phone services, the vast majority of their transactions are made in person through a network of independent agents in the United States. Viamericas agents are independent businesses (usually small stores of some type) that collect the money from the person sending the remittance and keep a portion of the fee as a commission for that service. The remittance is then paid out at a Viamericas affiliated location chosen by the sender, usually a bank or supermarket.

\footnotetext{
${ }^{6}$ In the year prior to our intervention, the fee paid by participants in this study was exactly $\$ 8$ for $96 \%$ of transactions under $\$ 1,000$.
} 
Study participants were recruited at five Viamericas agent locations in the suburbs of Washington, DC. Despite working in five locations, due to wide variations in the numbers of Viamericas customers in each store more than $80 \%$ of our sample comes from just two of these agents. Potential participants were approached by survey staff after sending a remittance and invited to participate in the study conditional on meeting three screening criteria. Participants must have been born in either Guatemala or El Salvador, must have just sent a remittance through Viamericas, ${ }^{7}$ and must have sent that remittance to the person that they consider to be their primary remittance recipient (PRR). Recruitment in this way ensures that the study population is made up of existing Viamericas customers. All migrants who agreed to participate received a $\$ 5$ credit to be spent at the agent location but which could not be used for remittance fees. ${ }^{8}$

Migrants who were eligible and agreed to participate first completed a short baseline survey that collected basic demographic information about the migrant and their primary remittance recipient, and information about remittances sent by the migrant. Following the survey, the surveyor administered the randomly assigned treatment(s). Randomization was done at the individual level and was stratified by agent location and in groups of 32 surveys to ensure that treatments were balanced over time. Each survey was labeled with an ID number and pre-assigned treatment status before being sent into the field and surveyors used the surveys in the order in which they received them. Treatment materials were placed in an envelope attached to each survey and surveyors did not know which treatment they would be administering until they opened the envelope at the end of the survey. There were two types of treatments which were cross randomized in a $2 \times 2$ design.

\section{Price discounts}

Migrants in this treatment group received a discount of \$3.01 off the remittance fee for remittances sent to their primary remittance recipient through Viamericas at the agent location where they were recruited. ${ }^{9}$ The discount was valid for 10 weeks and there was no limit on the number of transactions. Migrants received a plastic discount card and surveyors wrote the name of the PRR and the expiration date on the card. In order to redeem the discount, migrants had to

\footnotetext{
${ }^{7}$ In many cases Viamericas agents also offer remittance services with other money transfer companies.

${ }^{8}$ The way in which this was implemented varied by location. Some chose to give out $\$ 5$ phone cards, while others offered more flexibility. Regardless, this credit was mostly used to purchase phone cards.

${ }^{9}$ The discount was $\$ 3.01$ (rather than $\$ 3.00$ ) in order to facilitate finding and analyzing the discounted transactions in the Viamericas management information system.
} 
present the card to the teller. We can verify in the transaction data that very few discounts were applied to remittances sent to other recipients or after the intended expiration date. ${ }^{10}$

\section{Education information}

Migrants in this treatment group were given an informational sheet entitled "Why should I send remittances for education?” The information focused on the low rates of secondary and tertiary school completion in their home countries and described the earnings differentials between those who had completed primary, secondary and tertiary schooling. Separate sheets were created for Guatemala and El Salvador. The surveyor went over the information in the sheet with the migrant and the migrant was given the flyer to take home. This education information treatment was included in the project design because this study is part of a larger project that focused on understanding new ways to promote using remittances for education. Although the results for this intervention will be presented, this paper will largely focus on the impacts and implications of the price discounts.

These treatments were cross randomized, so migrants were randomly assigned to four groups: T0 - Control, T1 - Education information only, T2 - Discount and education information, and T3 - Discount only. Survey work began in late December 2012 and concluded in mid-April 2013. The last discount expired 10 weeks later in late June 2013. 946 migrants were surveyed in total. $^{11}$

Participating migrants were also contacted by phone for an endline survey. The goal of the endline survey was to capture remittance behavior during the 10 week discount period and consequently an effort was made to contact all subjects as close as possible to the day after the expiration of their discount. In the case of the control group, the contact occurred relative to the day that their discount would have expired had they been in the discount group (10 weeks

\footnotetext{
${ }^{10}$ Participating stores were reimbursed by the project for the discounts and additionally received a $\$ 1$ incentive for each discount that was correctly applied. All participating agents also received a one-time payment to compensate for staff training and other time costs of participating in the project.

${ }^{11}$ The length and detail of the baseline survey were limited by the recruitment strategy of intercepting participants immediately after they had sent a remittance, when most participants were not available to participate in a longer survey. In the days following this initial interaction participants were contacted by phone to complete another survey that contained more detailed information about their relationship with their family and a set of experimental questions that are the subject of a separate paper. $72 \%$ of these additional baseline surveys were completed. A subset of family members in El Salvador and Guatemala were additionally interviewed by phone about remittances and their relationship with the migrant. Because some store owners only agreed to participate on the condition that the research staff would not contact family members, only $18 \%$ of family members were interviewed. These surveys of family members in the home country are not used in the analysis presented in this paper.
} 
following their recruitment into the study.) The survey staff was largely successful in performing these interviews as scheduled: the median number of days between expiration and interview is two. The completion rate for the follow-up survey was $71 \%$.

\section{Viamericas data}

A key contribution of this study is that, in addition to survey measures of remittances at baseline and endline, we have access to administrative data on remittances sent by our participants through our partner money transmission operator (Viamericas) during the 10 weeks of our study as well as before and after. When migrants agreed to participate in the study the surveyors collected the transaction number of the remittance they had just sent. This number allowed Viamericas to identify the participant in their database and provide the research team with the participant's transaction history. We examine administrative data for 50 weeks after the baseline survey interaction (40 weeks post discount) for all study participants. This includes transactions for all recipients, not just the PRR, and allows us to identify to whom the remittance was sent, how much it was for, the fee that was paid, and whether or not a discount was applied.

\section{Threats to identification of the price effect}

Although the randomized design of this project ensures the identification of a causal effect, other factors can threaten the interpretation of the effect of the price treatment. Because the goal of the study is to understand the impact of the discount in remittance fees the project was designed to overcome these potential threats. First, because the analysis will rely heavily on transaction data from Viamericas, the analysis may overestimate an impact of the discount by not considering that migrants may have reduced remittances sent through other companies and increased those sent with Viamericas to take advantage of the discount. We address this possibility in two ways. First, we limit participation in the study to existing Viamericas customers. Second, in both the baseline and follow-up survey we ask detailed questions about what companies migrants are using to send the remittances they report, allowing us to directly document shifting from other companies to Viamericas.

A second threat to the interpretation of the discount effect is that migrants may send remittances for other people in their network. As long as the migrant physically performs the transaction (even if someone else has provided the funds), the discount can be applied. For this reason we limit the use of the discount card to remittances sent to the migrant's pre-identified primary remittance recipient, therefore making it difficult for others to benefit unless they also 
wish to send a remittance to the participating migrant's primary recipient. ${ }^{12}$ A related issue is that funds could be sent to the PRR either by the participating migrant or by others through the migrant to the PRR with the intention that the PRR would then distribute them to their intended recipients. This would also tend to overstate the impact of the discount. To address this possibility, we ask a set of questions in the follow up survey specifically designed to understand whether or not this behavior is occurring.

A final issue that may affect our estimates is that migrants may choose to shift their remittance behavior across time. In other words, they may send more remittances during the discount period to take advantage of the lower price, inter-temporally substituting remittances that they would have sent after the discount period ended. Again, this would tend to overstate the impact of the remittance discounts. However, because we have access to Viamericas transaction data after the discounts have ended, we are able to explicitly test for this inter-temporal substitution.

\section{Sample and balance tests}

As described in the previous section, study participants are migrants from Guatemala or El Salvador who have sent remittances through our partner company (Viamericas) at one of their participating agent locations in the suburbs of Washington, DC. The principal analyses in this paper will be performed on migrants who were interviewed at baseline using Viamericas administrative transaction data. We were able to match 941 of the 946 surveyed migrants to the Viamericas transaction data. Because we were able to match over $99 \%$ of the surveyed migrants, the matched sample will form our main analysis sample. Figure 1 shows how they are broken down in the different treatments. We conduct some analyses using the endline survey conducted by phone approximately 10 weeks after the initial baseline survey. There are 665 migrants in the endline sample which is a completion rate of 71\%. The endline survey contains information about the migrant's remittance behavior during the discount period and primarily allows us to check for remittances sent through other remittance companies.

Baseline summary statistics for the full sample are presented in Table 1. Data comes both from the baseline survey and from the Viamericas transaction data for the 12 months prior to

\footnotetext{
12 Stores were not reimbursed for discounts given to recipients other than those identified as the PRR, therefore giving them a strong incentive to comply with this restriction.
} 
enrollment in the study. $28 \%$ of migrants are female and their average age is $34.76 \%$ of the sample is from Guatemala and the migrants have been in the United States for an average of 9 years. 77\% of the named primary remittance recipients are female and these recipients are migrants' parents (38\%), spouses (24\%), siblings (15\%), and children (7\%). The migrants in this sample are heavy remitters, reporting that they remit, on average, $35 \%$ of their income to 1.7 households in their home country. Data on remittance amounts is available from both the self-reported survey data and the administrative data. The self-reported remittance amounts are somewhat higher than the administrative amounts. Although this may be partly due to the self-reported data including remittances from other channels, migrants were screened into the sample on the basis of being Viamericas customers and report sending very few remittances through other channels. Migrants report sending, on average, approximately 19 remittances through Viamericas in the year before the survey, and only one through other agencies. The discrepancies are more likely due to measurement error in the self-reporting of remittances. ${ }^{13,14}$ According to the transaction data, migrants sent, on average, $\$ 5,188$ in remittances the year before the survey. $\$ 3,125$ went to the identified PRR and \$2,064 went to other recipients. ${ }^{15}$

Because this is a randomized experiment it is important to verify that the randomization was successful in producing groups with similar characteristics. This ensures that treatment effects are indeed an impact of the treatments and not due to underlying differences between the groups. Table 2 shows means of variables by treatment group in both the baseline survey data and the transaction data and p-values for F-tests of whether the means in each treatment group are equal to the control group and whether all four groups are jointly equal to each other. Across variables the sample is very well balanced with no more significant differences than would be expected by chance.

\section{Results}

\footnotetext{
${ }^{13}$ An additional possibility is that migrants report remittances that may have been sent under a different name, for example through their spouse. While migrants consider those remittances in the total amount they report, the transaction data would miss those transactions.

${ }^{14}$ Discrepancies between self-reported remittance data and administrative data have been previously documented by Akee and Kapur (2012) and Aycinena, Martinez and Yang (2010).

${ }^{15}$ There is also a discrepancy between the transaction data and the self-reported data in the percentage of remittances going to the primary recipient, with the self-reported data having a much higher percentage. This is possibly due to the fact that migrants may send remittances to different individual recipients in the same household for a variety of reasons (for example, who is available to pick the money up). Migrants may consider these funds as all going to the primary recipient, but the transaction data will register the remittances as being sent different people.
} 


\section{A. Estimation:}

Because this is a randomized experiment, treatment effects can be causally identified using a simple estimation strategy. As a reminder from the previous section, the four different groups are referred to as follows:

- $\quad$ T0: Pure control group

- T1: Education information only

- T2: Discounts and information

- T3: Discounts only

The main results in this paper are estimated using the following equation:

$$
\text { outcome }_{i j}=\beta_{0}+\beta_{1} T 3_{i j}+\beta_{2} T 2_{i j}+\beta_{3} T 1_{i j}+\delta_{j}+\varepsilon_{i j}
$$

where $i$ indexes each individual migrant and $j$ indexes each stratification cell of 32 surveys. The outcomes consist of a number of different variables relating to use of remittance discounts, number of remittances sent, and total amounts of remittances. $T 3_{i j}, T 2_{i j}$, and $T 1_{i j}$ are indicator variables for each of the treatment groups and the corresponding coefficient is therefore the difference in the outcome variable between that treatment group and the omitted control group (T0). These are the intent-to-treat effects of each treatment relative to the control group. $\delta_{j}$ are stratification cell fixed effects for each group of 32 surveys, and each regression includes 35 stratification cells. $\varepsilon_{i j}$ is the error term, and is adjusted for heteroskedasticity.

\section{B. Results using transaction data}

We now present the results of estimating equation 1 using the Viamericas transaction data. Because the discount period lasted for 10 weeks, for most outcomes we present the results in five different 10 week periods: the 10 week discount period (the 10 weeks following recruitment into the study), and the periods 1 to 10, 11 to 20, 21 to 30, and 31 to 40 weeks after the discount expired. For those migrants who received an offer of a price discount (groups T2 and T3) these time periods correspond to the 10 weeks they were eligible to use their discount card and the 10 week periods following the expiration of that discount.

When considering the impact of the price discount on behavior, it is first important to verify that migrants actually made use of the discount, because if they did not, we should not expect the discount to have a large impact on behavior. It is also important to verify that the discount program was applied in accordance to project rules. Table 3 presents these results. Panel 1 presents results 
for transactions to all recipients, panel 2 for only those transactions sent to the PRR, and panel 3 for transactions sent to other recipients. Each panel also provides p-values for the equality of the different treatment effects to each other and a test for whether coefficients on T2 and T3 (the two groups that received price discounts) are jointly equal to zero.

Columns 1 through 3 of Table 3 examine use of the discount during the discount period. Column 1 looks at the impact of the treatment on the mean discount used (only for those who sent a remittance), column 2 at the impact on the total discount amount over the 10 weeks, and column 3 on the number of times the discount was used. The discount variables are expressed as negative numbers, so the project discount would show up in the transaction data as -3.01. Therefore we would expect the treatment effects in columns 1 and 2 (mean and total discount amounts) to be negative.

The results show that the discount card worked largely as intended. Migrants in both T2 and T3 are much more likely to have utilized the discounts than migrants in the control group or in T1, who should not have had access to the discount cards. Additionally, the coefficients in panel 2 for transactions sent to the PRR are much larger than those in panel 3 for transactions sent to other recipients. Recall that the discount card was valid only for remittances sent to the PRR. These results show that while it appears there was some slippage (use to other recipients is not zero), overall the discounts were applied as intended.

Migrants in T2 and T3 use the discount at a similar rate, using an average of about 1.5 discounts and saving approximately $\$ 4.50$ over the course of the discount period. Although migrants do make use of the discounts, it does not appear that they used the discount in every possible transaction. The mean discount in transactions to the PRR among those migrants who remitted to their PRR during the discount period (column 1) is approximately $\$ 1.50$ in both T2 and T3. Because the discount was \$3.01, this indicates that not all migrants utilized their discount cards.

Columns 4 through 6 of Table 3 present the same analyses for the first 10 week period after the discount expired. Because the discount was no longer valid during this period, we should not see an impact of the treatment on discount use if the project was implemented as intended. Indeed, the results show that few discounts were applied after the discount period and those that were applied were not applied differentially by treatment group. 
Now that we have verified that migrants do indeed make use of the discount cards, we can turn to the central question of this paper: whether or not this price reduction had an impact on remittance behavior. Because the discount lowers the price of each transaction, the first step is to analyze whether or not this discount affected the number of transactions sent by the migrant. Table 4 presents these results. All transactions are in panel 1, transactions to the PRR are in panel 2, and transactions to other recipients are in panel 3. Columns 1 through 5 show the results for number of transactions sent during the discount period and in each of the subsequent four 10 week periods respectively. Overall, it appears that the discount did motivate migrants to send more transactions during the discount period. Migrants in the discount only group (T3) sent about 0.56 more remittances than migrants in the control group, a 19.0\% increase. The coefficient on the discount plus information group is also positive, but smaller in magnitude and not statistically significant. Panel 2 shows that this increase in number of transactions is attributable to an increase in transactions to the PRR. Migrants in both T2 and T3 make statistically significantly more transactions to the PRR than do migrants in the control group. Migrants in T2 send 0.41 more transactions, a 22\% increase, and migrants in T3 send 0.69 more transactions, a 36\% increase.

The stronger impacts on transactions to the PRR than for overall transactions suggests that there may be some switching away from other recipients to the PRR because only the PRR is eligible for the discount. ${ }^{16}$ In panel 3, the coefficients on transactions to other recipients are negative for both T2 and T3, but they are small compared to the effects for the PRR and not statistically significant. Overall, although there may be some amount of switching, it does not outweigh an overall increase in transactions caused by the discount offer. Additionally, there is no impact of the information treatment (T1) on any of these outcomes.

Columns 2 through 5 examine the impact of the discount in four 10 week periods after the expiration of the discount. Examining the time period after the expiration of the discount allows us to verify that the documented increase in transactions is a true increase and not just evidence of inter-temporal substitution by the migrants in order to take advantage of discount. If there is indeed inter-temporal substitution occurring, we would expect to see negative impacts of the treatments in the weeks following the expiration of the discounts. Conversely, discount use may have also led

\footnotetext{
${ }^{16}$ One would especially expect to see switching behavior if migrants sometimes send to different members of the same household, however it is not possible to group recipients by household in the transaction data.
} 
to sustained increases in transactions after the period expired and this analysis will also allow us determine whether or not that has occurred.

There is no evidence that the number of transactions fell after the discount period ended (panel 1). In fact, transactions continue to be higher in T3 relative to the control group in the first 10 week after period. Migrants in T3 send 0.5 more transactions in the first 10 weeks after the discounts expire, an effect that is significant at the $10 \%$ level. The coefficient in the second 10 weeks after the discount is also positive, but smaller and no longer statistically significant. The effect has faded completely by the third and fourth post periods. The discount only treatment appears to have led to increases in transactions that persisted well past the expiration of the discount. Interestingly, in the after periods there is no evidence of switching between recipients (panels 2 and 3).

A visual representation of the results for total transactions over time is presented in Figure 2. Panel 2a shows total transactions in 2 week bins relative to the treatment period for all recipients, panel $2 \mathrm{~b}$ for transactions to the PRR, and panel 2c for transactions to other recipients. These figures contain data for the 10 weeks before the treatment period, the 10 weeks of the discount period, and the 40 weeks after. For ease of visualization, the figures show the transaction averages only for the control group (T0) and the discount only treatment group (T3). The two-week period in which migrants were recruited is excluded from the graph for presentational purposes (by design, all migrants sent a remittance the day they were recruited, so there is a large spike in remittances in the recruitment period.)

In all three panels, the treatment and control groups follow the same trend in the pretreatment period. During the discount period, the T3 line is well above the T0 line in both panels 2a and $2 \mathrm{~b}$. This trend continues after the discount period has ended and fades away by about 16 weeks following the expiration of the discount. Consistent with the regression results, Panel 2c shows that there is perhaps a slight decrease in transactions to other recipients during the discount period, but both before and after there is little difference between the control group and T3.

The results thus far indicate that the discount treatment caused migrants to send more remittance transactions both to their PRR and overall. The next question of interest is then whether or not this increase in transactions resulted in an overall increase in the amount of funds remitted by the migrant, or whether the migrants simply took advantage of the discount to send more transactions in smaller amounts. To answer this question we can examine the impacts of the 
discount both on mean transaction size and total remittances sent. Table 5 presents the results for mean transaction size for all recipients in panel 1, the PRR in panel 2, and all others in panel 3. Column 1 presents the results for the discount period and columns 2 through 5 for the four after periods. Because the dependent variable for these regressions is mean transaction amount, the sample for each regression is those migrants who sent a remittance to the indicated recipient during each period. Given that treatment influences whether or not a migrant sent a remittance at all (and therefore inclusion in this sample), the results for mean transaction amount should be interpreted with caution.

Overall there is very little evidence that the discount resulted in a change in the mean transaction amount. The coefficients for T3 in all three panels during the discount period are negative, but the standard errors are very large. Additionally, there is no consistent pattern in coefficients across time periods. Despite increases in the number of transactions in first 10 week period following the discount, the coefficients in column 2 of Table 5 are either positive or close to zero. However, again these results are not statistically significant.

An analysis of total amount sent by the migrant avoids issues of sample selection. Table 6 examines this question by looking at total remittances in the Viamericas transaction data sent by the migrant to all recipients, the PRR, and other recipients. Again we look at transactions made during the discount period and in the four 10 week periods after the discount expired. Because the total remittance variable has a number of very high outliers, we focus on the inverse hyperbolic sine transformation of total remittances, a specification very similar to log transformation that reduces the influence of outliers but which is not undefined at zero. ${ }^{17}$

The results for remittances sent to all recipients, the PRR, and other recipients are in panels 1 , 2, and 3 respectively. The coefficient in panel 1 on the discount only treatment for remittances to all recipients is positive and statistically significant at the $10 \%$ level, suggesting that, at least in $\mathrm{T} 3$, the discount treatment is causing migrants to send home more in total remittances. The coefficients on remittances to the PRR are positive and those to others are negative, but neither are statistically significant. The negative coefficients on the remittances to others is again suggestive of some degree of switching between recipients, but not enough to counteract an overall increase in remittances sent during the discount period.

${ }^{17}$ The inverse hyperbolic sine transformation is defined as $\log \left(\mathrm{y}_{\mathrm{i}}+\left(\mathrm{yi}_{\mathrm{i}}^{2}+1\right)^{1 / 2}\right)$. 
Next, in columns 2 through 5 we examine whether this increase in remittances persists after the discount period has ended, as it did for the number of transactions. The results show that the increased remittance levels do persist after the discount period has ended for those migrants in the discount only group. There is an increase in overall remittances in both of the first two post periods, statistically significant at the $10 \%$ level, but this effect fades away and is no longer detectable in the third and fourth post-discount periods. Mirroring the results for number of transactions in Table 4, there no evidence of switching between recipients in the first two after periods. The effect is concentrated among the PRRs (panel 2) but the coefficients on the discount only treatment for other recipients (panel 3) are actually positive (though not statistically significant).

Across time periods for overall remittances and remittances to the PRR in Table 6, the coefficients for T2 (discount and information) are generally positive but not statistically significant, while the coefficients for other recipients are negative. These results are somewhat suggestive that the discount and information treatment increased remittances, but the effect is small relative to the discount only treatment. At the same time, while the coefficients for the information only treatment group (T1) are mostly positive, they are never statistically significant. For remittances to the PRR in particular, the estimates are very close to zero. Therefore it does not seem that the education information actually encouraged migrants to send more home. Given this, the relative lack of impact for the discount and information (T2) treatment is somewhat surprising. One possibility is that the information on education made migrants more concerned about whether the remittances they were sending would be properly used by recipients. A "decoy effect" of this sort could have dampened the effect of the discount. In an experiment on promoting savings by migrants in their home country, Ashraf et al (forthcoming) find patterns consistent with a decoy effect among migrants from El Salvador: demand for a particular savings product that improves migrant control over savings is higher when it is offered alongside another product whose marketing emphasizes the importance of migrant control over remittance uses. ${ }^{18}$

Table 7 presents the same results as Table 6, but the dependent variable is remittances in dollars, truncated at the $95^{\text {th }}$ percentile of the distribution. Given the nature of the distribution of the remittance variable, our preferred specification is the inverse hyperbolic sine transformation

\footnotetext{
${ }^{18}$ Decoy effects, or shifts in preference for a certain option when presented with another option that might be thought to be irrelevant, have been found in other studies as well, such as Laran et al (2011) and Chatterjee and Rose (2012).
} 
(Table 6) but we show these results for completeness. During the discount period, T3 results in large increases in remittances to the PRR and decreases for other recipients. The combined effect is positive, but small and not statistically significant. In the first two post-discount periods there are similarly large (and statistically significant) increases in remittances to the PRR, but no corresponding decrease to other recipients. The overall coefficients in panel 1 are therefore large and positive, though they are not statistically significant. Again, the impact of T3 tapers off through the third and fourth post-discount periods. Except for the overall impact during the discount period, these dollar results match the pattern of the results in Table 6, although they are less precise.

Overall, the results from the transaction data show that the discount treatments increased the number of transactions sent by migrants, and additionally increased the total amount sent. These results mirror those in Aycinena, Martinez, and Yang (2010) who find that total remittances increase by much more than the amount of the discount that was offered. Going beyond the results in Aycinena, Martinez, and Yang (2010), we additionally find that the effects of the discounts continue to persist beyond the 10 week discount. Remittances remain higher in the discount groups for 20 weeks after recipients are no longer eligible to receive discounts.

C. Results using endline survey data

The benefit of working with Viamericas transaction data is that we have access to rich and accurate data on transactions that is not prone to the same type of measurement error as is remittance data collected in surveys. However, the major limitation of the transaction data is that it only contains records of transactions sent through Viamericas, and migrants have access to a wide range of companies, sometimes located in the same physical location, through which they can send remittances. A major concern for the validity of our results would then be that migrants in the discount groups may simply be choosing to send remittances through Viamericas because of the discount that they would have otherwise sent through another company. Because migrants in the control group have no such motivation, this behavior could account for the treatment effects that we see.

The most important way in which we address this problem is that we require all migrants to be customers of Viamericas at baseline. Because migrants tend to use the same remittance 
company as much as possible, ${ }^{19}$ we can expect that most of the migrants would have used Viamericas even in the absence of the discount. Baseline survey reports confirm that most participants are loyal Viamericas customers. Migrants report sending, on average, approximately 19 remittances through Viamericas in the year before the survey and only one through other companies. However, we can also use endline survey data, collected right after the discounts expired, to examine whether migrants report using different remittance channels.

$71 \%$ of migrants in the full sample were successfully surveyed at endline. Before examining the results, it is important to examine whether or not completion of that survey was related to treatment. Table 8 presents the impact of the treatments on attrition in column 1. Unfortunately, the endline sample suffers from a significant amount of attrition that is differential by treatment group, with migrants in both T2 and T3 being significantly less likely to complete the endline survey than migrants in the control group. The effects are large: 12 percentage points for T2 and 9 percentage points for T3. Given this level of differential attrition, we consider the results from the transaction data to be our main results, and will present results from the endline survey only to provide some evidence on the question of whether or not migrants are switching between companies. However, in Appendix Table A1 we replicate Table 6 using the transaction data in the sample that completed the endline survey. Although the magnitudes vary and precision suffers due to the reduced sample, the pattern of results is very similar, suggesting that the bias in the results from the differential attrition may be minimal. In Appendix Table A2 we additionally show that the endline sample is balanced on baseline characteristics despite the differential attrition. Furthermore, Table 8 also examines whether attrition is correlated with baseline values of the key outcome variables, namely number of transactions and amount remitted. Columns 2 and 3 of Table 8 show these correlations for the 365 days prior to recruitment and the 10 weeks prior to recruitment respectively using the transaction data. There is no evidence that attrition is related to baseline remittances, and additionally there is no evidence that attrition is related to a set of baseline characteristics collected during the baseline survey (results not shown).

Table 9 presents the results for remittance amounts from the endline survey data. Panel 1 shows results for the inverse hyperbolic sine transformation and panel 2 shows results in dollars

\footnotetext{
${ }^{19}$ Both sender and recipient information are saved in the agent computer, making subsequent transactions easier. Different companies also may have different payout points for the cash pickup. Trust is also an important component for migrants sending large amounts of money.
} 
truncated at the $95^{\text {th }}$ percentile. The survey data allows us to analyze remittances sent to the PRR and other recipients through Viamericas and through other channels. On the endline survey migrants were asked to list every remittance they sent during the 10 week discount period and the company that they used to send it. Overall the results from the endline survey are strong, and even more indicative of an increase in remittances than the transaction data. However, because of the attrition to the endline survey, we do not want to focus on these results, instead only using this data to look for evidence of switching between remittance companies. Columns 7, 8, and 9 report results for remittances sent through other channels. There is no evidence using either the inverse hyperbolic sine transformation or the remittance amount in dollars that there is a decrease in remittances sent through other channels in the two discount treatment groups. The coefficients for both T2 and T3 are small for all specifications and are never statistically significant.

The endline survey also contained a number of questions that were intended to measure whether or not any impacts of the discount treatments were true changes in remittances. Table 10 presents the results of analyzing the answers to those questions. One concern is that because the discount was only valid for the PRR migrants might send remittances to the PRR for the PRR to distribute to others. We have already seen in the transaction data that while there may be some switching from other recipients to the PRR, it does not account for the entire increase in remittances. Two questions on the survey examine this specifically, asking the migrant whether they have asked the PRR to distribute remittances within their household (column 1) or outside of their household (column 2). There is no evidence that migrants in the discount treatments were more likely to do this than migrants in the control group.

A related concern is that others in the United States may ask the migrant to send remittances to the PRR either for the PRR themselves or for the PRR to distribute to others in order to take advantage of the discount. A series of questions examines this issue. Specifically, we ask whether someone in the migrant's household has sent a remittance to the PRR (column 3), whether someone outside of the household has sent a remittance to the PRR (column 4), whether the migrant has sent remittances to others to be given to the PRR (column 5), whether anyone has given the migrant money to send to the PRR (column 6), and whether anyone has given the migrant money to send to the PRR so that they will distribute it to other people (column 7). Overall, these questions do not provide much evidence that people are sending remittances through the migrant to take advantage of the discount. There are only two significant coefficients for the discount only group 
(T3) and one of those (column 4) suggests that more people have actually sent remittances to the PRR. If people were asking the migrant to send remittances for them, that coefficient should be negative for the discount group. The significant coefficient in column 3 is potentially indicative of a problem. However, overall there are very few positive responses to the questions in columns 3 through 7 and it seems unlikely that any issue they represent could be driving the increase in remittances.

\section{Discussion and Conclusion}

This study examines the impact of short-term discounts for remittance fees on remittance behavior. Migrants from Guatemala and El Salvador who were existing customers of our partner organization were randomly chosen to receive $\$ 3.01$ off remittance fees that were around $\$ 8$ for remittances up to $\$ 1,000$ in value. The treatment had large impacts on remittances, increasing both the number of transactions and the total amount sent. The treatment effect persists for 20 weeks after the discount expires before fading out. The results are consistent with the large impacts of remittance prices on remittances found by Aycinena, Martinez, and Yang (2010), while for the first time using data from the post-treatment period to show persistence in the impact of the discount.

While our results are difficult to explain in the context of standard fully rational economic models, they are consistent with behavioral models with reference dependence and status quo bias, such as Tversky and Kahneman (1991), Masatlioglu and Ok (2005), and Masatlioglu and Ok (2014). Remittance recipients may have reference-dependent preferences with respect to the amount of remittances they expect to receive from migrants per time period (e.g., in terms of dollars of remittances received per month). When remittances received shift over time, recipients' reference points may adjust accordingly to some degree. It is possible that migrants may not fully anticipate shifts in recipients' reference points with respect to remittances received. In response to the temporary discounts we offered, migrants increased the number (and total money amount) of remittances sent during the discount period, and perhaps intended for these increases to be offset by reductions in remittances immediately after the discounts ended. In other words, migrants may have intended to inter-temporally substitute, shifting a later remittance into the discount period to take advantage of the discount. 
These increases in remittances during the 10 week discount period may have led remittance recipients to raise their reference points for per-period remittance receipts, with these higher reference points persisting into the post-discount period. In the post-discount period, recipients would then expect to continue receiving higher remittance amounts, and use their bargaining power in their relationship with migrants to induce this. ${ }^{20}$ The migrant therefore could not immediately reduce remittances to their pre-discount levels, but instead would do so only gradually. This is the pattern we see in our results. It is worth emphasizing that this explanation requires not only reference-dependence on the part of remittance recipients, but also at least partial naïveté on the part of migrants with respect to recipient reference-dependence. If migrants fully understood in advance the process by which recipients' reference points for remittances were set, they would anticipate the shift in reference point and likely refrain from responding to the discounts in the first place.

From a policy standpoint, our results suggest that temporary discounts can have large impacts on remittance behavior, and may be an important means of stimulating remittances in the short term. ${ }^{21}$ This type of policy could be useful when a temporary increase in remittances would be beneficial to the home country, for example in response to negative shocks such as natural disasters or acute economic downturns. However, our results also suggest that the migrant response may have been large specifically because the discount was temporary, and therefore this study may not reveal much about the impact of permanent price reductions. It may be that the temporary discount had large impacts because the migrants intended to make inter-temporal substitutions, and subsequently found that they were unable to quickly reduce remittance payments post discount. Permanent reductions would presumably not induce this intent to substitute across time. Further research would be needed to understand how a permanent price reduction would affect remittance behavior.

\section{References}

Adams, Jr., Richard H. 2004. "Remittances and Poverty in Guatemala.” World Bank Policy Research Working Paper No. 3418.

\footnotetext{
${ }^{20}$ See McKenzie, Gibson, and Stillman (2013), Ambler (2014), and De Weerdt, Genicot, and Mesnard (2014) for evidence of recipient bargaining power in remittance relationships.

${ }^{21}$ That said, it may not be possible to repeatedly exploit migrants' partial naïveté with temporary discounts. Once migrants realize that raising remittances leads to shifts in recipients' reference points, they may cease responding to future temporary discounts. Whether migrants do learn about remittance-recipient reference dependence is an empirical matter that should be investigated in future work.
} 
Adams, Jr., Richard H. 2005. "Remittances, Household Expenditure and Investment in Guatemala.” World Bank Policy Research Working Paper No. 3532.

Akee, Randall and Devesh Kapur. 2012. "Remittances and Rashomon,” Center for Global Development Working Paper 285.

Ambler, Kate. 2014. “Don’t Tell on Me: Experimental Evidence of Asymmetric Information in Transnational Households.” IFPRI Discussion Paper 01312.

Ambler, Kate, Diego Aycinena, and Dean Yang, “Channeling Remittances to Education: A Field Experiment among Migrants from El Salvador,” American Economic Journal: Applied Economics, forthcoming.

Ashraf, Nava, Diego Aycinena, Claudia Martinez A., and Dean Yang. "Savings in Transnational Households: A Field Experiment among Migrants from El Salvador.” Review of Economics and Statistics, forthcoming.

Aycinena, Diego, Claudia Martinez A., and Dean Yang. 2010. “The Impact of Remittance Fees on Remittance Flows: Evidence from a Field Experiment Among Salvadoran Migrants,” mimeo, University of Michigan.

Chatterjee, Promothesh and Randall L. Rose, "Do Payment Mechanisms Change the Way

Consumers Perceive Products?” Journal of Consumer Research, 38(6), April 2012.

Clemens, Michael and Timothy Ogden. 2013. “Migration as a Strategy for Household Finance: A Research Agenda on Remittances, Payments, and Development,” Financial Access Initiative Working Paper.

Cox Edwards, Alejandra and Manuelita Ureta. 2003. "International Migration, Remittances, and Schooling: Evidence from El Salvador,” Journal of Development Economics, 72(2): 429-461.

De Luna Martínez, José. 2005. “Workers’ Remittances to Developing Countries: A Survey with Central Banks on Selected Public Policy Issues,” World Bank Policy Research Working Paper 3638.

De Weerdt, Joachim, Garance Genicot, and Alice Mesnard. 2014. “Asymmetry of Information within Family Networks.” IZA DP No. 8395.

Freund, Caroline and Nikola Spatafora. 2005. "Remittances: Transaction Costs, Determinants, and Informal Flows,” World Bank Policy Research Working Paper 3704.

Frias, Michael. 2004. “Linking International Remittance Flows to Financial Services: Tapping the Latino Market,” Federal Deposit Insurance Corporation Supervisory Insights, 1(2). 
Gibson, John, David Mckenzie, and H. Rohorua. 2006. "How cost elastic are remittances? Evidence from Tongan migrants in New Zealand,” Pacific Economic Bulletin, 21(1):112-128. Masatlioglu, Yusufcan and Efe A. Ok. 2005. "Rational Choice with Status Quo Bias,” Journal of Economic Theory, 121(1): 1-29.

Masatlioglu, Yusufcan and Efe A. Ok. 2013. "A Canonical Model of Choice with Initial Endowments," Review of Economic Studies, forthcoming.

McKenzie, David, John Gibson, and Steven Stillman. 2013. “A Land of Milk and Honey with Streets Paved with Gold: Do Emigrants have Over-optimistic Expectations about Incomes Abroad?” The Journal of Development Economics 102: 116-127.

Laran, Juliano, Amy Dalton, and Eduardo Andrade, “The Curious Case of Behavioral Backlash: Why Brands Produce Priming Effects and Slogans Produce Reverse Priming Effects,” Journal of Consumer Research, 37, April 2011.

Orozco, Manuel. 2002. “Attracting Remittances: Market, Money, and Reduced Costs,” report commissioned by the Multilateral Investment Fund of the IADB.

Orozco, Manuel and Steven R. Wilson. 2005. “Making Migrant Remittances Count,” in Donald F. Terry and Steven R. Wilson, eds., Beyond Small Change: Making Migrant Remittances Count. Washington, DC: Inter-American Development Bank.

Orozco, Manuel and Rachel Fedewa. 2006. "Leveraging Efforts on Remittances and Financial Intermediation,” Integration and Regional Programs Department, IADB, Working Paper 24.

Pew Hispanic Center. 2002. Billions in Motion: Latino Immigrants, Remittances, and Banking.

Washington, DC: Pew Hispanic Center and Multilateral Investment Fund.

Ratha, Dilip. 2005. “Remittances: A Lifeline for Development,” Finance and Development, 42(4). Ratha, D., and J. Riedberg. 2005. “On Reducing Remittance Costs,” working paper, World Bank. Terry, Donald F. and Steven R. Wilson, eds. 2005. Beyond Small Change: Making Migrant Remittances Count. Washington, DC: Inter-American Development Bank.

Theoharides, Caroline. 2013. "Manila to Malaysia, Quezon to Qatar: International Migration and the Effects on Origin-Country Human Capital.” Mimeo, University of Michigan.

Tversky, Amos and Daniel Kahneman. 1991. "Loss Aversion in Riskless Choice: A ReferenceDependent Model,” The Quarterly Journal of Economics, 106(4): 1039-1061. 
Yang, Dean and Claudia Martinez A. 2005. Remittances and Poverty in Migrants' Home Areas: Evidence from the Philippines. In Caglar Ozden and Maurice Schiff (Eds.), International Migration, Remittances, and the Brain Drain, World Bank.

Yang, Dean. 2006. "Why Do Migrants Return to Poor Countries? Evidence from Philippine Migrants’ Exchange Rate Shocks,” Review of Economics and Statistics, 88(4): 715-735.

Yang, Dean and HwaJung Choi. 2007. “Are Remittances Insurance? Evidence from Rainfall Shocks in the Philippines,” World Bank Economic Review, 21(2): 219-248.

Yang, Dean. 2008a. “Coping with Disaster: The Impact of Hurricanes on International Financial Flows, 1970-2002,” B.E. Journal of Economic Analysis and Policy: 8(1) (Advances), Art. 13. Yang, Dean. 2008b. “International Migration, Remittances, and Household Investment: Evidence from Philippine Migrants’ Exchange Rate Shocks,” Economic Journal, 118: 591-630.

Woodruff, Christopher and Rene Zenteno. 2007. "Migration Networks and Microenterprises in Mexico.” Journal of Development Economics 82(2), 509-528.

World Bank. 2006. Global Economic Prospects 2006: Economic Implications of Remittances and Migration. Washington, DC.

World Bank. 2007. Close to Home: The Development Impact of Remittances in Latin America. Washington, DC.

World Bank. 2013. "Migration and Development Brief 20,” Migration and Remittances Unit, Development Prospects Group, Apr. 19. 
Figure 1: Treatments

\begin{tabular}{c|c|c|} 
& \multicolumn{1}{c}{$\begin{array}{c}\text { No education } \\
\text { information }\end{array}$} & $\begin{array}{c}\text { Education } \\
\text { information }\end{array}$ \\
\cline { 2 - 3 } No discount & $\mathrm{N}=232$ & $\mathrm{~N}=230$ \\
\cline { 2 - 3 } Discount & $\mathrm{N}=479$ \\
\cline { 2 - 3 } & $\mathrm{N}=247$ & $\mathrm{~N}=232$ \\
\cline { 2 - 3 } & $\mathrm{N}=479$ & $\mathrm{~N}=462$
\end{tabular}


Figure 2a: Total transactions in 2 week bins relative to treatment period - All recipients

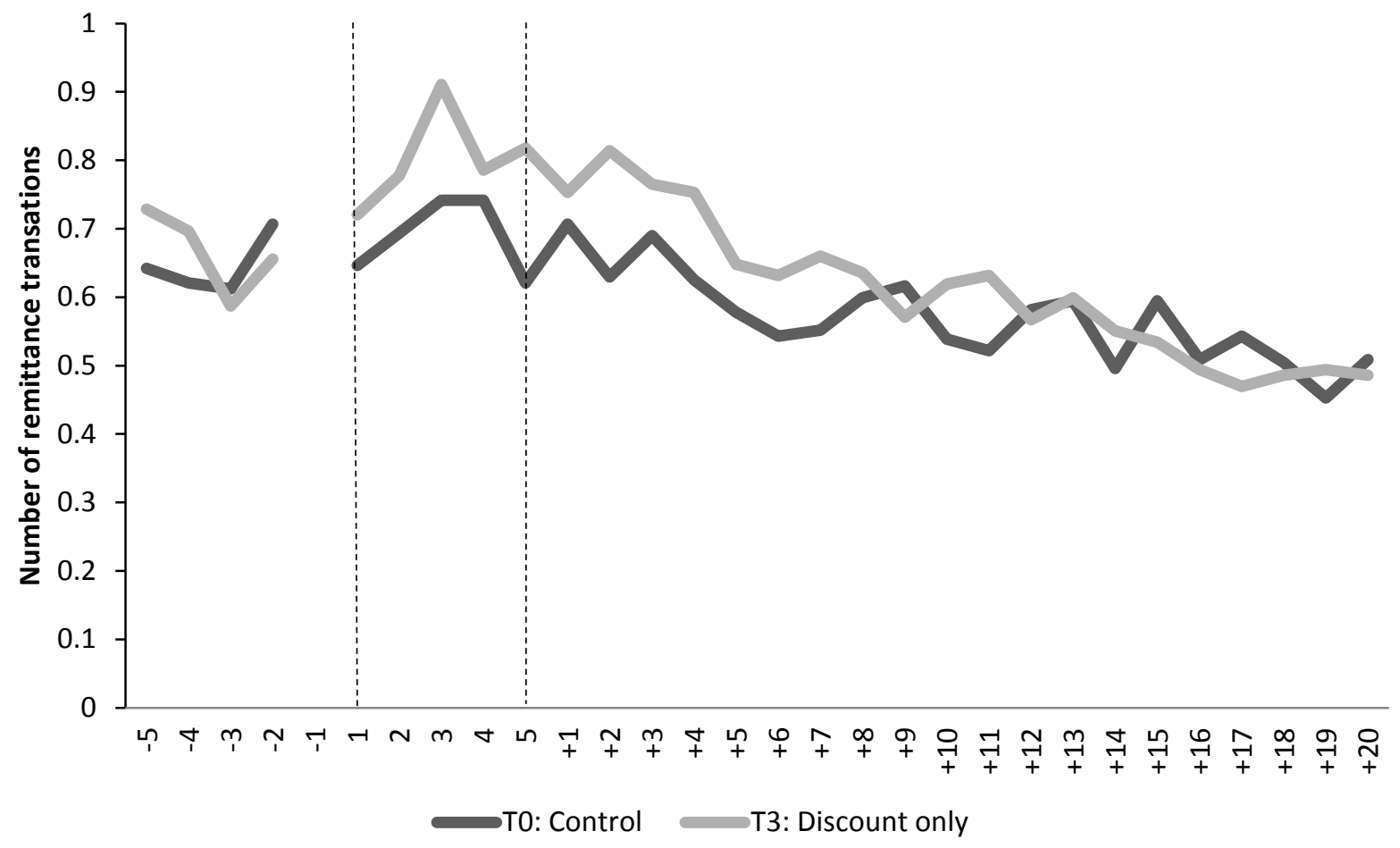

Figure 2b: Total transactions in 2 week bins relative to treatment period - primary remittance recipient (PRR) only

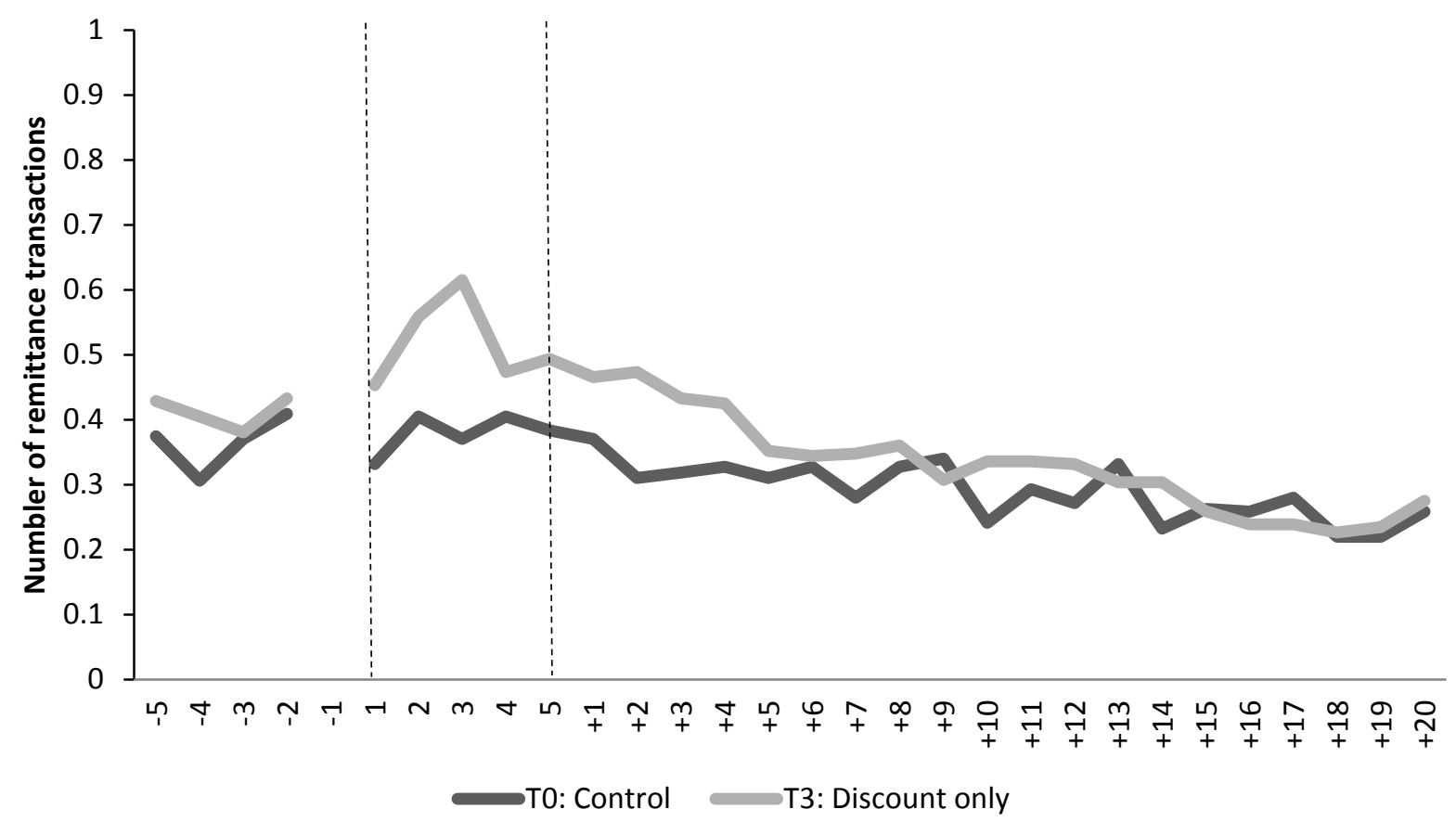


Figure 2c: Total transactions in 2 week bins relative to treatment period - Other recipients

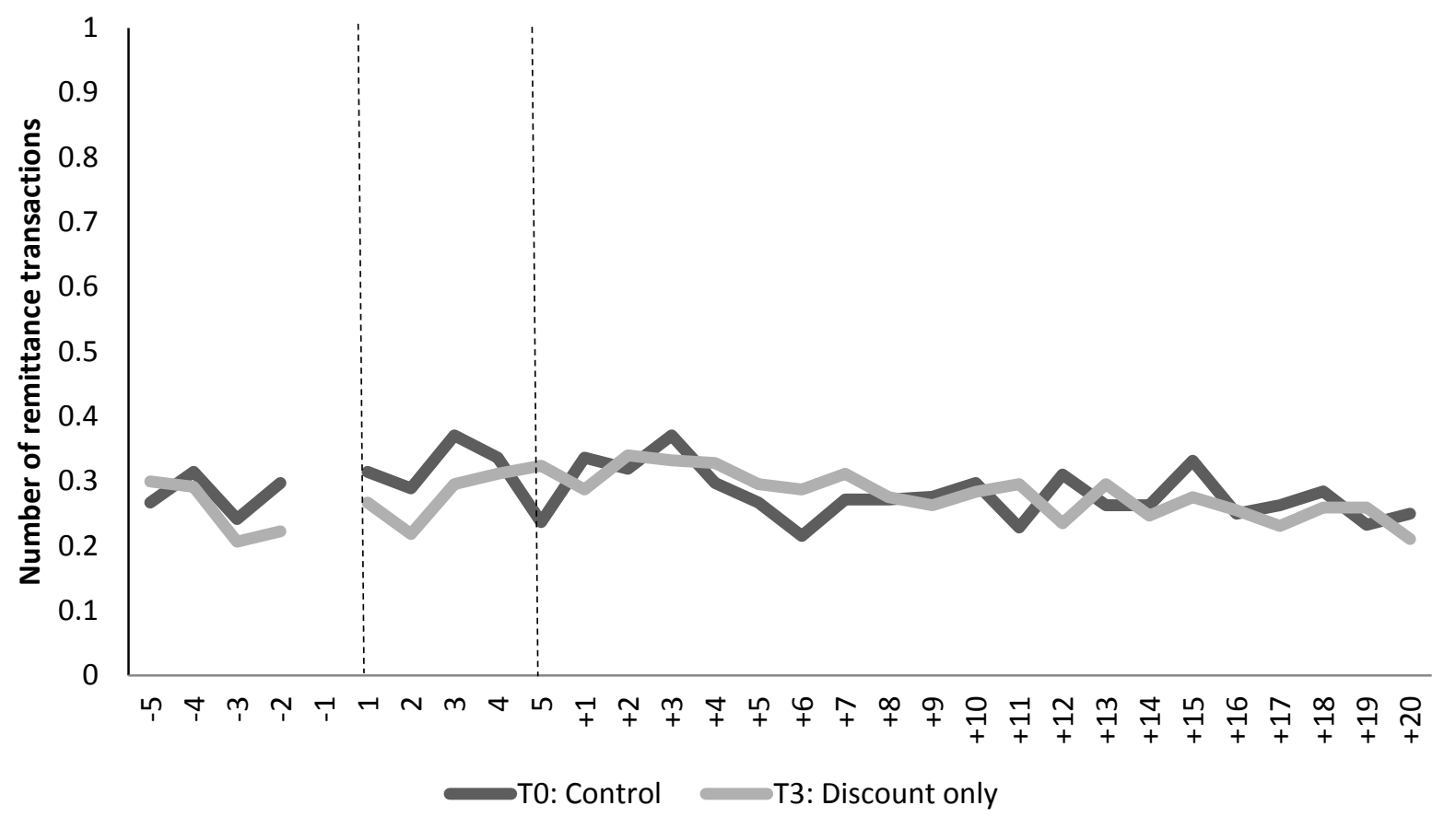

Notes for Figure 2: Y-axis variable is number of remittance transactions made in each two week period calculated with Viamericas transaction data. Panel A: Total number of remittance transactions. Panel B: Remittance transactions to primary remittance recipient (PRR). Panel C: Remittance transactions to other recipients. Time periods on $\mathrm{X}$-axis are two-week periods relative to the remittance discount period. From left, periods -5 to -1 are pre-discount, periods 1 to 5 are the discount period, and periods +1 to +20 are post-discount. 
Figure 3a: CDF of inverse hyperbolic sine transformation of total remittances sent: During discount period

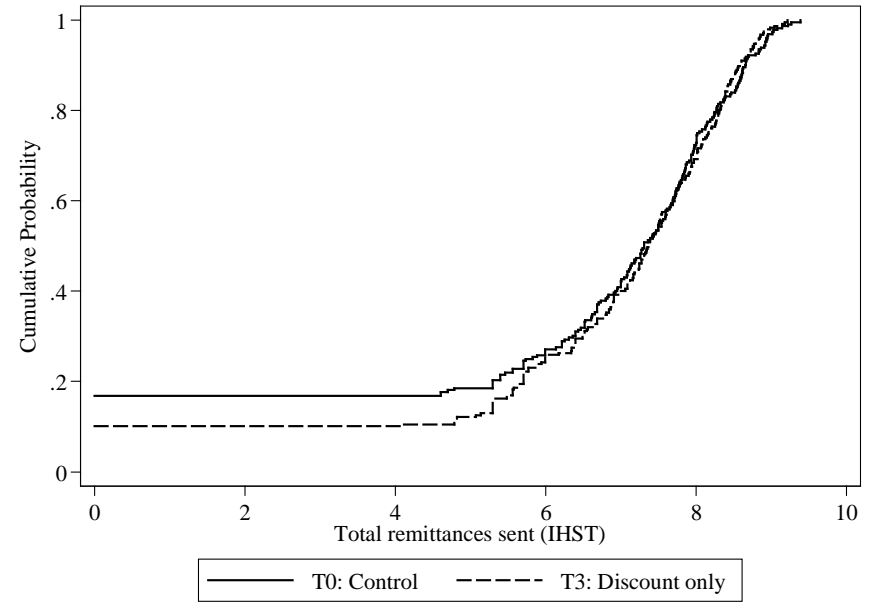

Figure 3b: CDF of inverse hyperbolic sine transformation of total remittances sent: 1 - 10 weeks after discount period

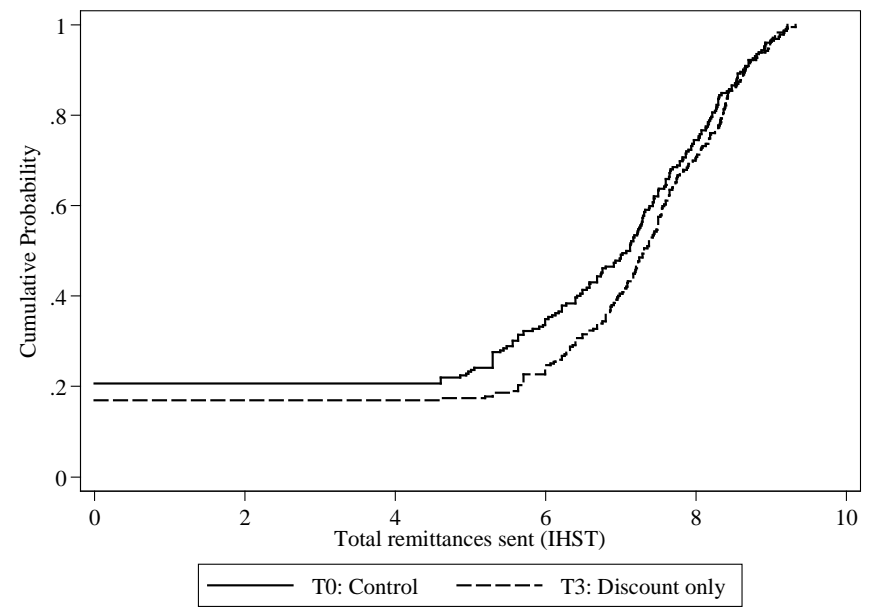

Figure 3c: CDF of inverse hyperbolic sine transformation of total remittances sent: $11-20$ weeks after discount period

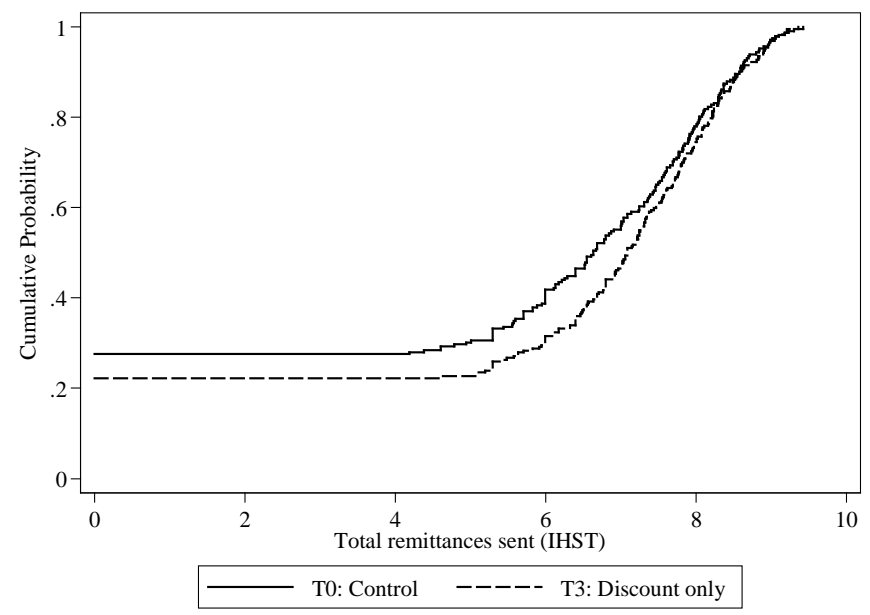


Figure 3d: CDF of inverse hyperbolic sine transformation of total remittances sent: 21 - 30 weeks after discount period

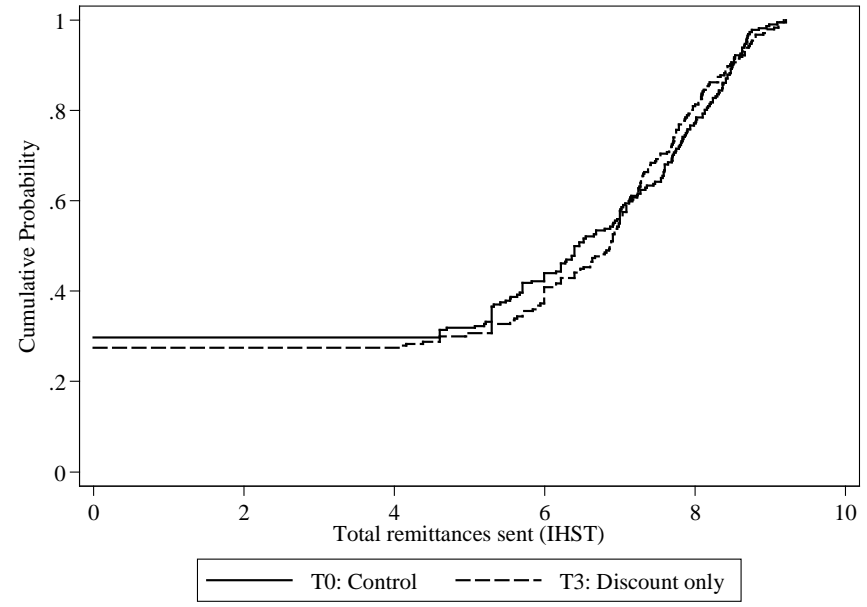

Figure 3e: CDF of inverse hyperbolic sine transformation of total remittances sent: 31 - 40 weeks after discount period

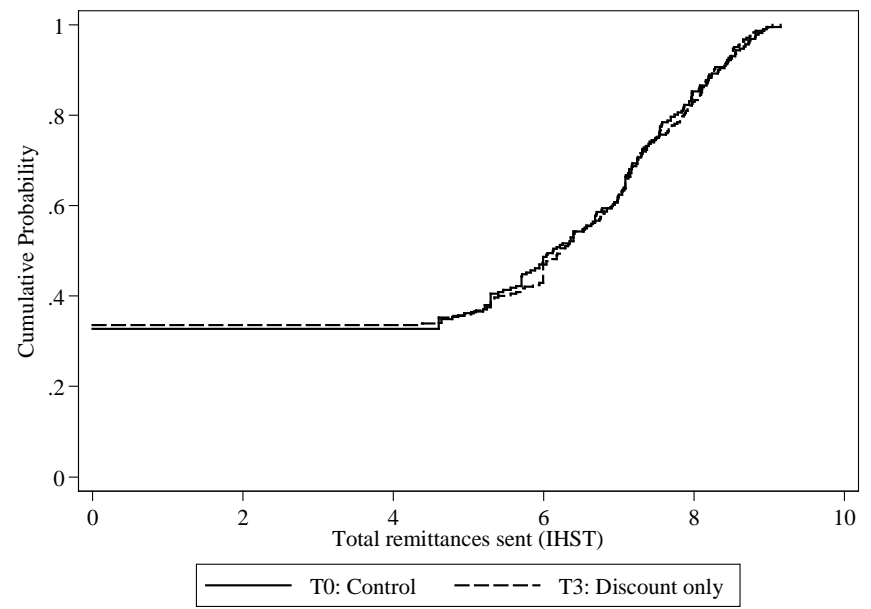

Notes for Figure 3: X-axis variables are the inverse hyperbolic sine transformation of total remittances sent calculated using Viamericas transaction data during the 10 week discount period (Panel A) and in the four 10 week periods following the expiration of the discount (Panels B through E). The inverse hyperbolic sine transformation of a variable $x$ is defined as $\log \left(x+\left(x^{2}+1\right)^{1 / 2}\right)$. 
Table 1: Baseline summary statistics

\begin{tabular}{|c|c|c|c|c|c|c|c|c|}
\hline Variable & Mean & Std. Dev. & Min & 10th pct. & Median & 90th pct. & Max & $\mathbf{N}$ \\
\hline Migrant is female & 0.28 & 0.45 & 0 & 0 & 0 & 1 & 1 & 941 \\
\hline Migrant age & 33.9 & 10.0 & 14.2 & 22.0 & 32.5 & 47.4 & 77.7 & 908 \\
\hline Migrant is from Guatemala & 0.76 & 0.42 & 0 & 0 & 1 & 1 & 1 & 923 \\
\hline Migrant years in US & 9.0 & 5.6 & 0 & 2 & 8 & 16 & 33 & 925 \\
\hline Migrant is married & 0.57 & 0.49 & 0 & 0 & 1 & 1 & 1 & 941 \\
\hline Migrant's spouse lives in the US & 0.51 & 0.50 & 0 & 0 & 1 & 1 & 1 & 519 \\
\hline Migrant number of children & 2.0 & 1.9 & 0 & 0 & 2 & 4 & 16 & 941 \\
\hline PRR is female & 0.77 & 0.42 & 0 & 0 & 1 & 1 & 1 & 939 \\
\hline Migrant remittances as percent of income & 35.1 & 17.6 & 0 & 10 & 30 & 50 & 80 & 855 \\
\hline Migrant annual remittance to PRR (\$) (survey reported) & 6,023 & 5,611 & 150 & 1,340 & 4,500 & 12,100 & 52,000 & 934 \\
\hline Mirgrant annual remittance to other hhs (\$) (survey reported) & 965 & 2,109 & 0 & 0 & 0 & 2,988 & 30,800 & 920 \\
\hline Migrant number of recipient households & 1.7 & 0.9 & 1 & 1 & 1 & 3 & 7 & 913 \\
\hline Number of transactions to PRR: Viamericas & 17.4 & 11.0 & 0 & 7 & 12 & 24 & 96 & 932 \\
\hline Number of transactions to PRR: Other channels & 0.8 & 2.6 & 0 & 0 & 0 & 4 & 30 & 932 \\
\hline Number of transactions to other recipients: Viamericas & 2.0 & 5.4 & 0 & 0 & 0 & 8 & 58 & 629 \\
\hline Number of transactions to other recipients: Other channels & 0.2 & 1.2 & 0 & 0 & 0 & 0 & 12 & 630 \\
\hline \multicolumn{9}{|l|}{ Migrant's highest level of education is... } \\
\hline ...none & 0.33 & 0.47 & 0 & 0 & 0 & 1 & 1 & 941 \\
\hline ...primary & 0.25 & 0.43 & 0 & 0 & 0 & 1 & 1 & 941 \\
\hline ...secondary & 0.08 & 0.27 & 0 & 0 & 0 & 0 & 1 & 941 \\
\hline ...university & 0.02 & 0.15 & 0 & 0 & 0 & 0 & 1 & 941 \\
\hline \multicolumn{9}{|l|}{ Primary recipient is migrant's... } \\
\hline ...parent & 0.38 & 0.49 & 0 & 0 & 0 & 1 & 1 & 941 \\
\hline ...spouse & 0.24 & 0.43 & 0 & 0 & 0 & 1 & 1 & 941 \\
\hline ...sibling & 0.15 & 0.36 & 0 & 0 & 0 & 1 & 1 & 941 \\
\hline ...child & 0.07 & 0.25 & 0 & 0 & 0 & 0 & 1 & 941 \\
\hline \multicolumn{9}{|l|}{ Transaction data - previous 365 days } \\
\hline All - total transactions & 16.9 & 14.8 & 0 & 3 & 13 & 36 & 115 & 941 \\
\hline All - total amount $(\$)$ & 5,188 & 4,671 & 0 & 510 & 3,695 & 12,139 & 25,700 & 941 \\
\hline All - mean transaction amount $(\$)$ & 354 & 314 & 13 & 113 & 266 & 680 & 2,980 & 937 \\
\hline PRR - total transactions & 9.5 & 9.7 & 0 & 1 & 6 & 22 & 77 & 941 \\
\hline PRR - total amount (\$) & 3,125 & 3,789 & 0 & 200 & 1,629 & 8,300 & 25,700 & 941 \\
\hline PRR - mean transaction amount (\$) & 362 & 383 & 13 & 96 & 241 & 703 & 3,000 & 930 \\
\hline Others - total transactions & 7.4 & 10.1 & 0 & 0 & 4 & 19 & 66 & 941 \\
\hline Others - total amount $(\$)$ & 2,064 & 2,971 & 0 & 0 & 775 & 5,873 & 21,845 & 941 \\
\hline Others - mean transaction amount (\$) & 333 & 377 & 35 & 80 & 200 & 752 & 2,950 & 749 \\
\hline
\end{tabular}

Notes: Sample is full sample of migrants recuited at baseline. Data comes from baseline survey and Viamericas transaction data. Sample varies slightly with missing values. 
Table 2: Baseline balance

\begin{tabular}{|c|c|c|c|c|c|c|c|c|c|}
\hline & \multirow[b]{2}{*}{ T0: Control } & \multicolumn{2}{|c|}{ Means } & \multicolumn{6}{|c|}{$P$-values } \\
\hline & & $\begin{array}{c}\mathrm{T} 1: \\
\text { Information }\end{array}$ & $\begin{array}{l}\text { T2: Info \& } \\
\text { Discounts }\end{array}$ & $\begin{array}{c}\text { T3: } \\
\text { Discounts }\end{array}$ & $\begin{array}{c}\mathrm{T} 0=\mathrm{T} 1= \\
\mathrm{T} 2=\mathrm{T} 3\end{array}$ & $\mathrm{~T} 0=\mathrm{T} 1$ & $\mathrm{~T} 0=\mathrm{T} 2$ & $\mathrm{~T} 0=\mathrm{T} 3$ & $N$ \\
\hline Migrant is female & 0.25 & 0.31 & 0.28 & 0.28 & 0.568 & 0.161 & 0.536 & 0.610 & 941 \\
\hline Migrant age & 33.2 & 33.8 & 34.8 & 33.7 & 0.358 & 0.517 & 0.079 & 0.568 & 908 \\
\hline Migrant is from Guatemala & 0.74 & 0.80 & 0.76 & 0.75 & 0.434 & 0.122 & 0.561 & 0.780 & 923 \\
\hline Migrant years in US & 8.9 & 8.4 & 9.6 & 9.0 & 0.177 & 0.300 & 0.238 & 0.837 & 925 \\
\hline Migrant is married & 0.50 & 0.56 & 0.62 & 0.62 & 0.024 & 0.156 & 0.009 & 0.008 & 941 \\
\hline Migrant's spouse lives in the US & 0.51 & 0.52 & 0.51 & 0.50 & 0.976 & 0.822 & 0.933 & 0.843 & 519 \\
\hline Migrant number of children & 1.8 & 2.0 & 2.0 & 2.1 & 0.442 & 0.247 & 0.237 & 0.123 & 941 \\
\hline $\mathrm{PRR}$ is female & 0.76 & 0.76 & 0.78 & 0.78 & 0.926 & 0.866 & 0.641 & 0.538 & 939 \\
\hline Migrant remittances as percent of income & 33.5 & 35.4 & 36.5 & 34.9 & 0.368 & 0.265 & 0.081 & 0.408 & 855 \\
\hline Migrant annual remittance to PRR (\$) (survey reported) & 5,846 & 6,092 & 6,244 & 5,922 & 0.874 & 0.639 & 0.448 & 0.883 & 934 \\
\hline Mirgrant annual remittance to other hhs (\$) (survey reported & 917 & 894 & 819 & 1,214 & 0.185 & 0.907 & 0.618 & 0.126 & 920 \\
\hline Migrant number of recipient households & 1.6 & 1.6 & 1.7 & 1.8 & 0.109 & 0.598 & 0.175 & 0.021 & 913 \\
\hline Number of transactions to PRR: Viamericas & 17.7 & 16.9 & 17.5 & 17.3 & 0.886 & 0.449 & 0.849 & 0.659 & 932 \\
\hline Number of transactions to PRR: Other channels & 0.9 & 1.0 & 0.9 & 0.6 & 0.544 & 0.760 & 0.902 & 0.286 & 932 \\
\hline Number of transactions to other recipients: Viamericas & 1.4 & 2.3 & 1.6 & 2.6 & 0.157 & 0.148 & 0.675 & 0.042 & 629 \\
\hline Number of transactions to other recipients: Other channels & 0.2 & 0.2 & 0.3 & 0.2 & 0.816 & 0.760 & 0.395 & 0.983 & 630 \\
\hline \multicolumn{10}{|l|}{ Migrant's highest level of education is... } \\
\hline ...none & 0.31 & 0.35 & 0.29 & 0.35 & 0.338 & 0.290 & 0.692 & 0.281 & 941 \\
\hline ...primary & 0.26 & 0.26 & 0.25 & 0.21 & 0.609 & 0.873 & 0.747 & 0.220 & 941 \\
\hline ...secondary & 0.06 & 0.09 & 0.09 & 0.08 & 0.685 & 0.289 & 0.302 & 0.403 & 941 \\
\hline ...university & 0.03 & 0.02 & 0.03 & 0.02 & 0.968 & 0.770 & 1.000 & 0.685 & 941 \\
\hline \multicolumn{10}{|l|}{ Primary recipient is migrant's... } \\
\hline ...parent & 0.42 & 0.38 & 0.39 & 0.34 & 0.409 & 0.379 & 0.567 & 0.097 & 941 \\
\hline ...spouse & 0.22 & 0.19 & 0.27 & 0.26 & 0.174 & 0.407 & 0.275 & 0.316 & 941 \\
\hline ...sibling & 0.14 & 0.15 & 0.15 & 0.16 & 0.903 & 0.669 & 0.795 & 0.463 & 941 \\
\hline ...child & 0.06 & 0.08 & 0.04 & 0.08 & 0.314 & 0.438 & 0.454 & 0.363 & 941 \\
\hline \multicolumn{10}{|l|}{ Transaction data - previous 365 days } \\
\hline All - total transactions & 16.5 & 18.1 & 15.8 & 16.9 & 0.405 & 0.235 & 0.641 & 0.734 & 941 \\
\hline All - total amount $(\$)$ & 5,205 & 5,566 & 4,816 & 5,171 & 0.394 & 0.406 & 0.369 & 0.936 & 941 \\
\hline All - mean transaction amount (\$) & 359 & 369 & 351 & 340 & 0.780 & 0.745 & 0.765 & 0.504 & 937 \\
\hline PRR - total transactions & 9.4 & 9.4 & 9.0 & 10.0 & 0.730 & 0.951 & 0.717 & 0.457 & 941 \\
\hline PRR - total amount $(\$)$ & 3,029 & 3,064 & 3,064 & 3,329 & 0.806 & 0.922 & 0.921 & 0.388 & 941 \\
\hline PRR - mean transaction amount $(\$)$ & 344 & 371 & 382 & 351 & 0.692 & 0.461 & 0.290 & 0.856 & 930 \\
\hline Others - total transactions & 7.1 & 8.7 & 6.8 & 6.9 & 0.144 & 0.091 & 0.736 & 0.826 & 941 \\
\hline Others - total amount $(\$)$ & 2,176 & 2,503 & 1,752 & 1,842 & 0.026 & 0.236 & 0.123 & 0.218 & 941 \\
\hline Others - mean transaction amount (\$) & 362 & 334 & 312 & 324 & 0.634 & 0.480 & 0.214 & 0.327 & 749 \\
\hline
\end{tabular}

Notes: Sample is full sample of migrants recuited at baseline. Data comes from baseline survey and Viamericas transaction data. Sample varies slightly with missing values. P-values come from regressions of each baseline variable on the treatment variables, including stratification cell fixed effects for survey group. 
Table 3: Impact of treatments on discount use

\begin{tabular}{|c|c|c|c|c|c|c|}
\hline & (1) & $(2)$ & (3) & (4) & (5) & (6) \\
\hline & \multicolumn{3}{|c|}{$\begin{array}{l}\text { Remittances sent during } 10 \text { week } \\
\text { discount period }\end{array}$} & \multicolumn{3}{|c|}{$\begin{array}{l}\text { Remittances sent } 1 \text { - } 10 \text { weeks } \\
\text { after discount period }\end{array}$} \\
\hline & $\begin{array}{l}\text { Mean } \\
\text { discount }\end{array}$ & $\begin{array}{c}\text { Total } \\
\text { discount }\end{array}$ & $\begin{array}{c}\text { Number of } \\
\text { discounts } \\
\text { used }\end{array}$ & $\begin{array}{c}\text { Mean } \\
\text { discount }\end{array}$ & $\begin{array}{l}\text { Total } \\
\text { discount }\end{array}$ & $\begin{array}{c}\text { Number of } \\
\text { discounts } \\
\text { used } \\
\end{array}$ \\
\hline \multicolumn{7}{|l|}{ Panel 1: All recipients } \\
\hline T3: Discount only & $\begin{array}{c}-1.003^{* * *} \\
{[0.0827]}\end{array}$ & $\begin{array}{c}-4.497 * * * \\
{[0.451]}\end{array}$ & $\begin{array}{c}1.496 * * * \\
{[0.150]}\end{array}$ & $\begin{array}{c}0.0166 \\
{[0.0163]}\end{array}$ & $\begin{array}{c}0.0294 \\
{[0.0664]}\end{array}$ & $\begin{array}{l}-0.00978 \\
{[0.0221]}\end{array}$ \\
\hline T2: Discount + information & $\begin{array}{l}-0.975 * * * \\
{[0.0840]}\end{array}$ & $\begin{array}{c}-4.214^{* * *} \\
{[0.439]}\end{array}$ & $\begin{array}{c}1.401^{* * *} \\
{[0.146]}\end{array}$ & $\begin{array}{c}0.0148 \\
{[0.0170]}\end{array}$ & $\begin{array}{c}0.0291 \\
{[0.0634]}\end{array}$ & $\begin{array}{l}-0.00964 \\
{[0.0211]}\end{array}$ \\
\hline T1: Information only & $\begin{array}{c}0.0154 \\
{[0.0372]}\end{array}$ & $\begin{array}{l}-0.0692 \\
{[0.193]}\end{array}$ & $\begin{array}{c}0.0231 \\
{[0.0642]}\end{array}$ & $\begin{array}{l}0.000177 \\
{[0.0233]}\end{array}$ & $\begin{array}{c}0.0153 \\
{[0.0771]}\end{array}$ & $\begin{array}{l}-0.00508 \\
{[0.0256]}\end{array}$ \\
\hline \multicolumn{7}{|l|}{$P$-values for tests of coefficients } \\
\hline T3 \& T2 jointly equal to zero & 0.000 & 0.000 & 0.000 & 0.590 & 0.887 & 0.887 \\
\hline $\mathrm{T} 3=\mathrm{T} 2$ & 0.798 & 0.640 & 0.635 & 0.800 & 0.995 & 0.994 \\
\hline $\mathrm{T} 3=\mathrm{T} 1$ & 0.000 & 0.000 & 0.000 & 0.353 & 0.836 & 0.836 \\
\hline $\mathrm{T} 2=\mathrm{T} 1$ & 0.000 & 0.000 & 0.000 & 0.423 & 0.831 & 0.832 \\
\hline Observations & 814 & 941 & 941 & 753 & 941 & 941 \\
\hline R-squared & 0.290 & 0.205 & 0.205 & 0.033 & 0.033 & 0.033 \\
\hline Control group mean & -0.05 & -0.19 & 0.06 & -0.02 & -0.08 & 0.03 \\
\hline \multicolumn{7}{|c|}{ Panel 2: All transactions to PRR } \\
\hline T3: Discount only & $\begin{array}{c}-1.499 * * * \\
{[0.106]}\end{array}$ & $\begin{array}{l}-4.218^{* * *} \\
{[0.447]}\end{array}$ & $\begin{array}{c}1.402 * * * \\
{[0.149]}\end{array}$ & $\begin{array}{l}0.00788 \\
{[0.0200]}\end{array}$ & $\begin{array}{l}-0.00969 \\
{[0.0545]}\end{array}$ & $\begin{array}{l}0.00322 \\
{[0.0181]}\end{array}$ \\
\hline T2: Discount + information & $\begin{array}{c}-1.414^{* * *} \\
{[0.109]}\end{array}$ & $\begin{array}{c}-3.876^{* * *} \\
{[0.418]}\end{array}$ & $\begin{array}{c}1.288 * * * \\
{[0.139]}\end{array}$ & $\begin{array}{l}0.00756 \\
{[0.0206]}\end{array}$ & $\begin{array}{c}0.00301 \\
{[0.0494]}\end{array}$ & $\begin{array}{l}-0.00100 \\
{[0.0164]}\end{array}$ \\
\hline T1: Information only & $\begin{array}{c}0.0184 \\
{[0.0562]}\end{array}$ & $\begin{array}{l}-0.0576 \\
{[0.187]}\end{array}$ & $\begin{array}{c}0.0191 \\
{[0.0621]}\end{array}$ & $\begin{array}{l}0.00278 \\
{[0.0227]}\end{array}$ & $\begin{array}{l}-0.0118 \\
{[0.0655]}\end{array}$ & $\begin{array}{l}0.00393 \\
{[0.0218]}\end{array}$ \\
\hline \multicolumn{7}{|l|}{$P$-values for tests of coefficients } \\
\hline T3 \& T2 jointly equal to zero & 0.000 & 0.000 & 0.000 & 0.922 & 0.966 & 0.966 \\
\hline $\mathrm{T} 3=\mathrm{T} 2$ & 0.537 & 0.560 & 0.560 & 0.980 & 0.797 & 0.797 \\
\hline $\mathrm{T} 3=\mathrm{T} 1$ & 0.000 & 0.000 & 0.000 & 0.775 & 0.974 & 0.974 \\
\hline $\mathrm{T} 2=\mathrm{T} 1$ & 0.000 & 0.000 & 0.000 & 0.804 & 0.810 & 0.810 \\
\hline Observations & 660 & 941 & 941 & 577 & 941 & 941 \\
\hline R-squared & 0.399 & 0.192 & 0.192 & 0.036 & 0.027 & 0.027 \\
\hline Control group mean & -0.08 & -0.19 & 0.06 & -0.02 & -0.04 & 0.01 \\
\hline \multicolumn{7}{|c|}{ Panel 3: All transactions to other recipients } \\
\hline T3: Discount only & $\begin{array}{c}-0.204^{* * *} \\
{[0.0544]}\end{array}$ & $\begin{array}{c}-0.279 * * * \\
{[0.0916]}\end{array}$ & $\begin{array}{c}0.0941^{* * *} \\
{[0.0304]}\end{array}$ & $\begin{array}{c}0.0129 \\
{[0.0136]}\end{array}$ & $\begin{array}{c}0.0391 \\
{[0.0383]}\end{array}$ & $\begin{array}{l}-0.0130 \\
{[0.0127]}\end{array}$ \\
\hline T2: Discount + information & $\begin{array}{c}-0.139 * * * \\
{[0.0474]}\end{array}$ & $\begin{array}{c}-0.338^{* *} \\
{[0.155]}\end{array}$ & $\begin{array}{c}0.113^{* *} \\
{[0.0514]}\end{array}$ & $\begin{array}{c}0.00716 \\
{[0.0148]}\end{array}$ & $\begin{array}{c}0.0261 \\
{[0.0410]}\end{array}$ & $\begin{array}{c}-0.00864 \\
{[0.0136]}\end{array}$ \\
\hline T1: Information only & $\begin{array}{c}-0.0136 \\
{[0.0183]}\end{array}$ & $\begin{array}{c}-0.0116 \\
{[0.0370]}\end{array}$ & $\begin{array}{c}0.00406 \\
{[0.0123]}\end{array}$ & $\begin{array}{l}-0.00805 \\
{[0.0278]}\end{array}$ & $\begin{array}{c}0.0271 \\
{[0.0412]}\end{array}$ & $\begin{array}{l}-0.00901 \\
{[0.0137]}\end{array}$ \\
\hline \multicolumn{7}{|l|}{$P$-values for tests of coefficients } \\
\hline T3 \& T2 jointly equal to zero & 0.000 & 0.001 & 0.001 & 0.440 & 0.399 & 0.399 \\
\hline $\mathrm{T} 3=\mathrm{T} 2$ & 0.345 & 0.744 & 0.759 & 0.373 & 0.370 & 0.370 \\
\hline $\mathrm{T} 3=\mathrm{T} 1$ & 0.000 & 0.002 & 0.002 & 0.375 & 0.389 & 0.389 \\
\hline $\mathrm{T} 2=\mathrm{T} 1$ & 0.008 & 0.049 & 0.050 & 0.504 & 0.958 & 0.956 \\
\hline Observations & 533 & 941 & 941 & 506 & 941 & 941 \\
\hline R-squared & 0.146 & 0.067 & 0.067 & 0.046 & 0.032 & 0.032 \\
\hline Control group mean & 0.00 & 0.00 & 0.00 & -0.01 & -0.04 & 0.01 \\
\hline
\end{tabular}


Table 4: Impact of treatments on total number of transactions

\begin{tabular}{|c|c|c|c|c|c|}
\hline & $(1)$ & $(2)$ & (3) & (4) & (5) \\
\hline & \multicolumn{5}{|c|}{ Dependent variable = Number of transactions... } \\
\hline & $\begin{array}{c}\text { During } \\
\text { discount } \\
\text { period }\end{array}$ & $\begin{array}{c}1 \text {-10 weeks } \\
\text { after }\end{array}$ & $\begin{array}{c}11-20 \\
\text { weeks after }\end{array}$ & $\begin{array}{c}21-30 \\
\text { weeks after }\end{array}$ & $\begin{array}{c}31-40 \\
\text { weeks after }\end{array}$ \\
\hline \multicolumn{6}{|l|}{ Panel 1: All recipients } \\
\hline T3: Discount only & $\begin{array}{l}0.563^{* *} \\
{[0.284]}\end{array}$ & $\begin{array}{c}0.500 * \\
{[0.280]}\end{array}$ & $\begin{array}{c}0.256 \\
{[0.267]}\end{array}$ & $\begin{array}{c}0.0914 \\
{[0.303]}\end{array}$ & $\begin{array}{l}-0.0902 \\
{[0.285]}\end{array}$ \\
\hline T2: Discount + information & $\begin{array}{c}0.290 \\
{[0.294]}\end{array}$ & $\begin{array}{c}-0.138 \\
{[0.287]}\end{array}$ & $\begin{array}{c}0.215 \\
{[0.288]}\end{array}$ & $\begin{array}{c}0.275 \\
{[0.320]}\end{array}$ & $\begin{array}{c}0.176 \\
{[0.309]}\end{array}$ \\
\hline T1: Information only & $\begin{array}{c}0.213 \\
{[0.295]}\end{array}$ & $\begin{array}{c}0.286 \\
{[0.302]}\end{array}$ & $\begin{array}{c}0.490 \\
{[0.304]}\end{array}$ & $\begin{array}{c}0.417 \\
{[0.328]}\end{array}$ & $\begin{array}{c}0.268 \\
{[0.295]}\end{array}$ \\
\hline \multicolumn{6}{|l|}{$P$-values for tests of coefficients } \\
\hline T3 \& T2 jointly equal to zero & 0.140 & 0.057 & 0.601 & 0.677 & 0.659 \\
\hline $\mathrm{T} 3=\mathrm{T} 2$ & 0.366 & 0.024 & 0.885 & 0.534 & 0.363 \\
\hline $\mathrm{T} 3=\mathrm{T} 1$ & 0.251 & 0.473 & 0.432 & 0.288 & 0.199 \\
\hline $\mathrm{T} 2=\mathrm{T} 1$ & 0.805 & 0.165 & 0.388 & 0.662 & 0.764 \\
\hline Observations & 941 & 941 & 941 & 941 & 941 \\
\hline R-squared & 0.153 & 0.203 & 0.163 & 0.156 & 0.136 \\
\hline Control group mean & 3.44 & 3.23 & 2.85 & 2.79 & 2.52 \\
\hline \multicolumn{6}{|c|}{ Panel 2: All transactions to PRR } \\
\hline T3: Discount only & $\begin{array}{c}0.691^{* * *} \\
{[0.218]}\end{array}$ & $\begin{array}{l}0.494 * * \\
{[0.205]}\end{array}$ & $\begin{array}{c}0.162 \\
{[0.198]}\end{array}$ & $\begin{array}{c}0.142 \\
{[0.197]}\end{array}$ & $\begin{array}{l}-0.0355 \\
{[0.185]}\end{array}$ \\
\hline T2: Discount + information & $\begin{array}{c}0.413^{* *} \\
{[0.206]}\end{array}$ & $\begin{array}{c}0.133 \\
{[0.195]}\end{array}$ & $\begin{array}{c}0.197 \\
{[0.205]}\end{array}$ & $\begin{array}{c}0.318 \\
{[0.208]}\end{array}$ & $\begin{array}{c}0.226 \\
{[0.191]}\end{array}$ \\
\hline T1: Information only & $\begin{array}{c}0.126 \\
{[0.212]}\end{array}$ & $\begin{array}{c}0.151 \\
{[0.206]}\end{array}$ & $\begin{array}{c}0.0714 \\
{[0.210]}\end{array}$ & $\begin{array}{c}0.120 \\
{[0.199]}\end{array}$ & $\begin{array}{c}0.190 \\
{[0.199]}\end{array}$ \\
\hline \multicolumn{6}{|l|}{$P$-values for tests of coefficients } \\
\hline T3 \& T2 jointly equal to zero & 0.005 & 0.046 & 0.590 & 0.310 & 0.312 \\
\hline $\mathrm{T} 3=\mathrm{T} 2$ & 0.217 & 0.072 & 0.859 & 0.382 & 0.152 \\
\hline $\mathrm{T} 3=\mathrm{T} 1$ & 0.015 & 0.105 & 0.655 & 0.910 & 0.235 \\
\hline $\mathrm{T} 2=\mathrm{T} 1$ & 0.194 & 0.928 & 0.550 & 0.331 & 0.856 \\
\hline Observations & 941 & 941 & 941 & 941 & 941 \\
\hline R-squared & 0.111 & 0.143 & 0.108 & 0.143 & 0.108 \\
\hline Control group mean & 1.90 & 1.64 & 1.52 & 1.39 & 1.24 \\
\hline \multicolumn{6}{|c|}{ Panel 3: All transactions to other recipients } \\
\hline T3: Discount only & $\begin{array}{c}-0.128 \\
{[0.193]}\end{array}$ & $\begin{array}{c}0.00608 \\
{[0.198]}\end{array}$ & $\begin{array}{c}0.0941 \\
{[0.187]}\end{array}$ & $\begin{array}{l}-0.0508 \\
{[0.235]}\end{array}$ & $\begin{array}{l}-0.0547 \\
{[0.212]}\end{array}$ \\
\hline T2: Discount + information & $\begin{array}{c}-0.122 \\
{[0.208]}\end{array}$ & $\begin{array}{c}-0.271 \\
{[0.208]}\end{array}$ & $\begin{array}{c}0.0185 \\
{[0.200]}\end{array}$ & $\begin{array}{l}-0.0429 \\
{[0.233]}\end{array}$ & $\begin{array}{l}-0.0491 \\
{[0.227]}\end{array}$ \\
\hline T1: Information only & $\begin{array}{c}0.0876 \\
{[0.198]}\end{array}$ & $\begin{array}{c}0.135 \\
{[0.211]}\end{array}$ & $\begin{array}{l}0.419 * \\
{[0.220]}\end{array}$ & $\begin{array}{c}0.297 \\
{[0.249]}\end{array}$ & $\begin{array}{c}0.0786 \\
{[0.208]}\end{array}$ \\
\hline \multicolumn{6}{|l|}{$P$-values for tests of coefficients } \\
\hline T3 \& T2 jointly equal to zero & 0.766 & 0.300 & 0.867 & 0.975 & 0.963 \\
\hline $\mathrm{T} 3=\mathrm{T} 2$ & 0.978 & 0.161 & 0.696 & 0.969 & 0.979 \\
\hline $\mathrm{T} 3=\mathrm{T} 1$ & 0.273 & 0.519 & 0.130 & 0.119 & 0.478 \\
\hline $\mathrm{T} 2=\mathrm{T} 1$ & 0.319 & 0.053 & 0.078 & 0.129 & 0.541 \\
\hline Observations & 941 & 941 & 941 & 941 & 941 \\
\hline R-squared & 0.100 & 0.122 & 0.100 & 0.078 & 0.083 \\
\hline Control group mean & 1.55 & 1.59 & 1.33 & 1.40 & 1.28 \\
\hline
\end{tabular}


Table 5: Impact of treatments on mean transaction amount

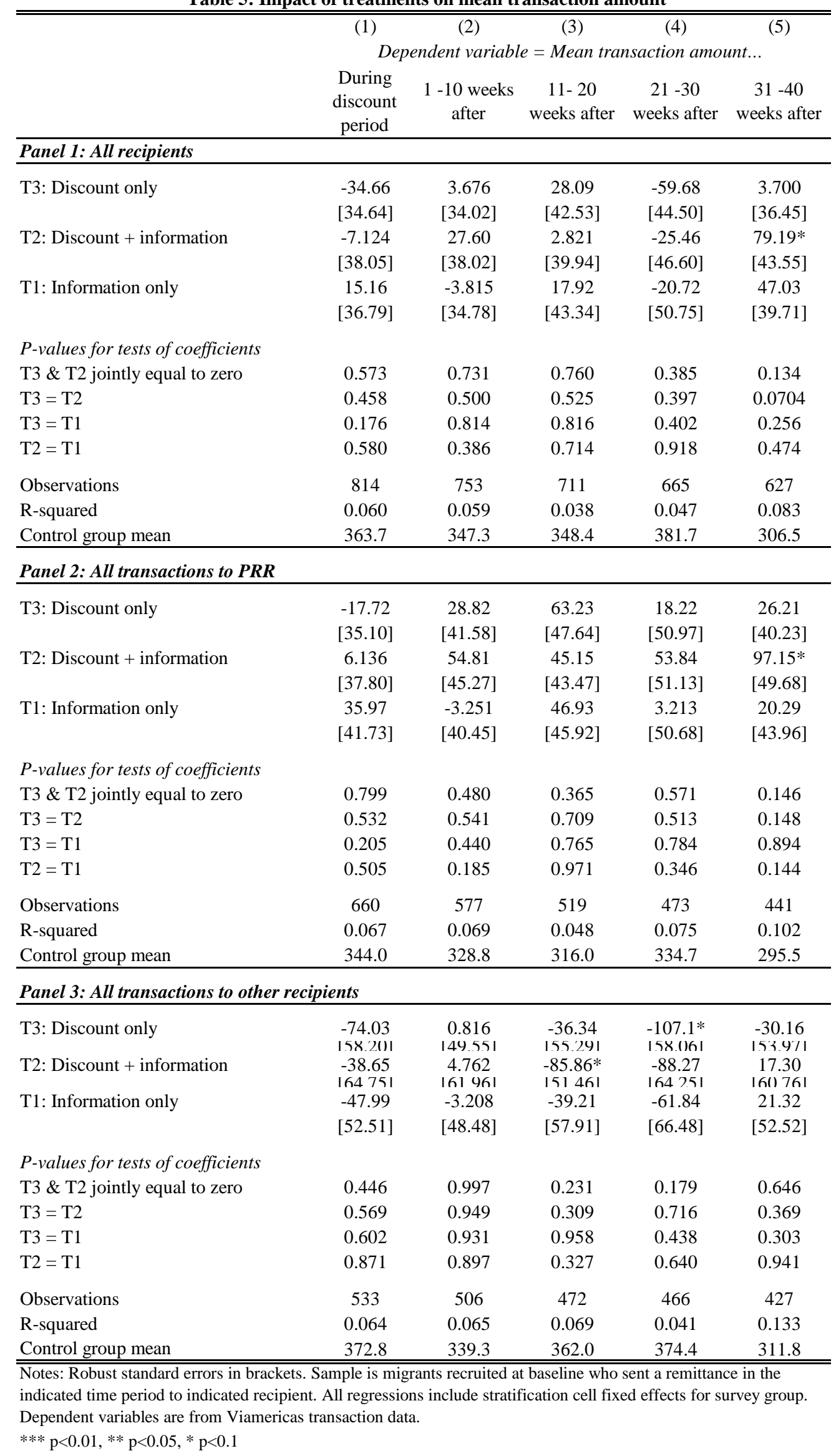


Table 6: Impact of treatments on remittances sent: Inverse hyperbolic sine transformation

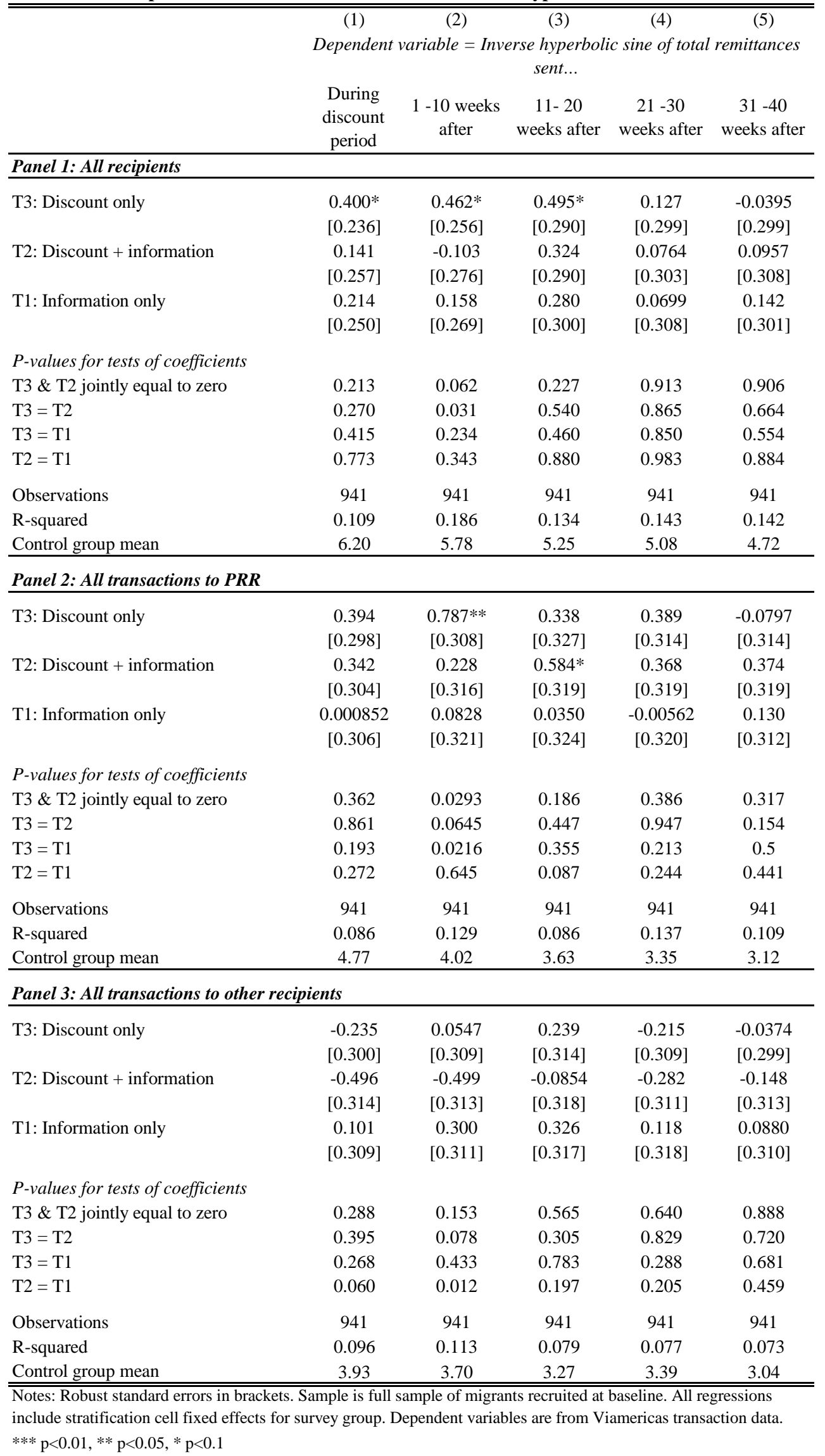


Table 7: Impact of treatments on remittances sent: Dollars truncated at 95th percentile

\begin{tabular}{|c|c|c|c|c|c|}
\hline & (1) & (2) & (3) & (4) & (5) \\
\hline & \multicolumn{5}{|c|}{ Dependent variable $=$ Dollars truncated at 95th percentile sent... } \\
\hline & $\begin{array}{c}\text { During } \\
\text { discount } \\
\text { period }\end{array}$ & $\begin{array}{c}1 \text {-10 weeks } \\
\text { after }\end{array}$ & $\begin{array}{c}11-20 \\
\text { weeks after }\end{array}$ & $\begin{array}{c}21 \text {-30 } \\
\text { weeks after }\end{array}$ & $\begin{array}{c}31-40 \\
\text { weeks after }\end{array}$ \\
\hline \multicolumn{6}{|l|}{ Panel 1: All recipients } \\
\hline T3: Discount only & $\begin{array}{c}8.823 \\
{[89.35]}\end{array}$ & $\begin{array}{c}136.4 \\
{[90.26]}\end{array}$ & $\begin{array}{c}113.9 \\
{[89.95]}\end{array}$ & $\begin{array}{c}-30.81 \\
{[83.87]}\end{array}$ & $\begin{array}{c}1.112 \\
{[75.87]}\end{array}$ \\
\hline T2: Discount + information & $\begin{array}{c}-8.097 \\
{[92.84]}\end{array}$ & $\begin{array}{c}16.54 \\
{[93.97]}\end{array}$ & $\begin{array}{c}52.35 \\
{[88.25]}\end{array}$ & $\begin{array}{c}63.48 \\
{[85.57]}\end{array}$ & $\begin{array}{l}161.9 * * \\
{[82.40]}\end{array}$ \\
\hline T1: Information only & $\begin{array}{c}-28.22 \\
{[89.39]}\end{array}$ & $\begin{array}{c}102.2 \\
{[94.68]}\end{array}$ & $\begin{array}{c}92.33 \\
{[89.45]}\end{array}$ & $\begin{array}{c}79.86 \\
{[86.89]}\end{array}$ & $\begin{array}{c}153.1^{*} \\
{[80.20]}\end{array}$ \\
\hline \multicolumn{6}{|l|}{$P$-values for tests of coefficients } \\
\hline T3 \& T2 jointly equal to zero & 0.983 & 0.254 & 0.449 & 0.525 & 0.086 \\
\hline $\mathrm{T} 3=\mathrm{T} 2$ & 0.853 & 0.191 & 0.493 & 0.264 & 0.049 \\
\hline $\mathrm{T} 3=\mathrm{T} 1$ & 0.672 & 0.708 & 0.813 & 0.197 & 0.055 \\
\hline $\mathrm{T} 2=\mathrm{T} 1$ & 0.825 & 0.370 & 0.655 & 0.851 & 0.918 \\
\hline Observations & 941 & 941 & 941 & 941 & 941 \\
\hline R-squared & 0.123 & 0.195 & 0.15 & 0.162 & 0.128 \\
\hline Control group mean & 1079 & 963.7 & 842.8 & 808.1 & 634.2 \\
\hline \multicolumn{6}{|l|}{ Panel 2: All transactions to PRR } \\
\hline T3: Discount only & $\begin{array}{c}133.1^{*} \\
{[68.59]}\end{array}$ & $\begin{array}{l}150.1^{* *} \\
{[63.00]}\end{array}$ & $\begin{array}{c}105.4^{*} \\
{[63.47]}\end{array}$ & $\begin{array}{c}35.48 \\
{[63.93]}\end{array}$ & $\begin{array}{c}53.37 \\
{[54.58]}\end{array}$ \\
\hline T2: Discount + information & $\begin{array}{c}104.0 \\
{[67.10]}\end{array}$ & $\begin{array}{c}119.0^{*} \\
{[65.17]}\end{array}$ & $\begin{array}{l}137.9 * * \\
{[62.53]}\end{array}$ & $\begin{array}{l}122.9^{*} \\
{[66.81]}\end{array}$ & $\begin{array}{c}148.9 * * * \\
{[56.77]}\end{array}$ \\
\hline T1: Information only & $\begin{array}{c}24.27 \\
{[67.00]}\end{array}$ & $\begin{array}{c}51.55 \\
{[63.75]}\end{array}$ & $\begin{array}{c}58.01 \\
{[60.34]}\end{array}$ & $\begin{array}{c}31.69 \\
{[61.65]}\end{array}$ & $\begin{array}{c}87.19 \\
{[54.80]}\end{array}$ \\
\hline \multicolumn{6}{|l|}{$P$-values for tests of coefficients } \\
\hline T3 \& T2 jointly equal to zero & 0.115 & 0.042 & 0.064 & 0.173 & 0.032 \\
\hline $\mathrm{T} 3=\mathrm{T} 2$ & 0.682 & 0.642 & 0.631 & 0.192 & 0.115 \\
\hline $\mathrm{T} 3=\mathrm{T} 1$ & 0.125 & 0.131 & 0.472 & 0.951 & 0.563 \\
\hline $\mathrm{T} 2=\mathrm{T} 1$ & 0.251 & 0.316 & 0.218 & 0.159 & 0.308 \\
\hline Observations & 941 & 941 & 941 & 941 & 941 \\
\hline R-squared & 0.08 & 0.122 & 0.105 & 0.122 & 0.104 \\
\hline Control group mean & 569.7 & 464 & 408.2 & 413.1 & 307.7 \\
\hline \multicolumn{6}{|c|}{ Panel 3: All transactions to other recipients } \\
\hline T3: Discount only & $\begin{array}{c}-116.7 * * \\
{[53.06]}\end{array}$ & $\begin{array}{c}2.229 \\
{[59.34]}\end{array}$ & $\begin{array}{c}-10.04 \\
{[58.84]}\end{array}$ & $\begin{array}{c}-45.25 \\
{[50.14]}\end{array}$ & $\begin{array}{c}-41.96 \\
{[43.58]}\end{array}$ \\
\hline T2: Discount + information & $\begin{array}{l}-94.75 * \\
{[57.12]}\end{array}$ & $\begin{array}{c}-98.03 \\
{[59.56]}\end{array}$ & $\begin{array}{c}-81.17 \\
{[56.86]}\end{array}$ & $\begin{array}{c}-34.53 \\
{[51.58]}\end{array}$ & $\begin{array}{c}-0.844 \\
{[48.48]}\end{array}$ \\
\hline T1: Information only & $\begin{array}{c}-11.38 \\
{[57.16]}\end{array}$ & $\begin{array}{c}48.24 \\
{[61.07]}\end{array}$ & $\begin{array}{c}34.25 \\
{[60.61]}\end{array}$ & $\begin{array}{c}47.82 \\
{[56.06]}\end{array}$ & $\begin{array}{c}57.38 \\
{[49.51]}\end{array}$ \\
\hline$P$-values for tests of coefficien & & & & & \\
\hline T3 \& T2 jointly equal to zero & 0.080 & 0.147 & 0.269 & 0.654 & 0.525 \\
\hline $\mathrm{T} 3=\mathrm{T} 2$ & 0.669 & 0.083 & 0.188 & 0.820 & 0.352 \\
\hline $\mathrm{T} 3=\mathrm{T} 1$ & 0.041 & 0.436 & 0.444 & 0.074 & 0.029 \\
\hline $\mathrm{T} 2=\mathrm{T} 1$ & 0.137 & 0.014 & 0.039 & 0.123 & 0.246 \\
\hline Observations & 941 & 941 & 941 & 941 & 941 \\
\hline R-squared & 0.09 & 0.121 & 0.087 & 0.069 & 0.06 \\
\hline Control group mean & 446.8 & 434.4 & 388.3 & 342.9 & 285 \\
\hline
\end{tabular}




\begin{tabular}{|c|c|c|c|}
\hline & (1) & $\begin{array}{c}\text { (2) } \\
\text { Endline completed } \\
\end{array}$ & (3) \\
\hline T3: Discount only & $\begin{array}{c}-0.0906 * * \\
{[0.0411]}\end{array}$ & & \\
\hline T2: Discount + information & $\begin{array}{c}-0.120 * * * \\
{[0.0421]}\end{array}$ & & \\
\hline T1: Information only & $\begin{array}{c}-0.0479 \\
{[0.0410]}\end{array}$ & & \\
\hline Number of transactions in prior 365 days & & $\begin{array}{c}0.000452 \\
{[0.00147]}\end{array}$ & \\
\hline Total amount remitted in prior 365 days & & $\begin{array}{c}0.00000258 \\
{[4.43 \mathrm{e}-06]}\end{array}$ & \\
\hline Number of transactions in prior 10 weeks & & & $\begin{array}{c}-0.00145 \\
{[0.00623]}\end{array}$ \\
\hline Total amount remitted in prior 10 weeks & & & $\begin{array}{c}0.00000253 \\
{[1.60 \mathrm{e}-05]}\end{array}$ \\
\hline Observations & 941 & 941 & 941 \\
\hline R-squared & 0.049 & 0.04 & 0.039 \\
\hline Control group mean & 0.772 & & \\
\hline
\end{tabular}


Table 9: Impact of treatments on remittances sent: Endline survey data

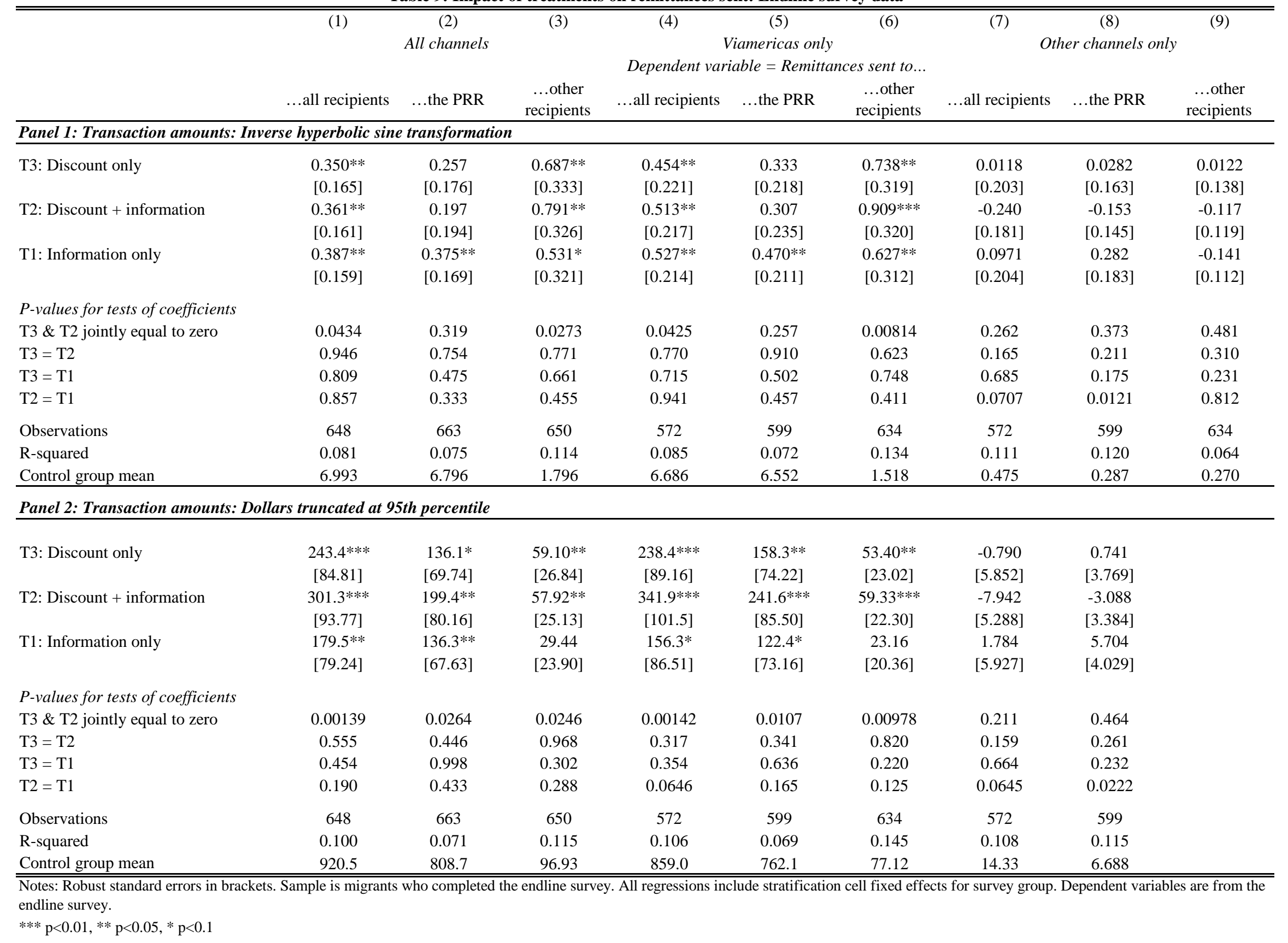


Table 10: Impact of treatments on distribution of remittances to others

(1)

(2)
Have you Have you Has someone asked PRR to asked PRR to within your

distribute

remittances

within their

household? distribute household (not remittances outside their household? you) sent a remittance to PRR?
(4)

(5)

Has anyone Have you sent outside of your remittances to household sent a remittance to PRR? others so that they will distribute them

(6)

(7)

Has anyone given you

Has anyone given you money to send money to send to PRR so that to PRR? to PRR? they distribute it to other people?

\begin{tabular}{|c|c|c|c|c|c|c|c|}
\hline \multirow[t]{2}{*}{ T3: Discount only } & -0.0114 & -0.0227 & $-0.0523 *$ & $0.0592 * *$ & 0.0216 & 0.00855 & 0.00772 \\
\hline & {$[0.0475]$} & {$[0.0419]$} & {$[0.0286]$} & {$[0.0268]$} & {$[0.0240]$} & {$[0.0140]$} & [0.00753] \\
\hline \multirow[t]{2}{*}{ T2: Discount + information } & 0.0266 & -0.0217 & 0.00299 & 0.0419 & 0.0229 & 0.00393 & $0.0223^{*}$ \\
\hline & {$[0.0508]$} & {$[0.0434]$} & {$[0.0349]$} & {$[0.0286]$} & {$[0.0248]$} & {$[0.0128]$} & {$[0.0128]$} \\
\hline \multirow[t]{2}{*}{ T1: Information only } & 0.0321 & -0.0450 & -0.0128 & 0.0397 & -0.000298 & -0.00284 & 0.00679 \\
\hline & {$[0.0493]$} & {$[0.0394]$} & {$[0.0307]$} & {$[0.0246]$} & [0.0193] & {$[0.0101]$} & {$[0.00579]$} \\
\hline \multicolumn{8}{|l|}{$P$-values for tests of coefficients } \\
\hline T3 \& T2 jointly equal to zero & 0.748 & 0.833 & 0.0938 & 0.0532 & 0.548 & 0.828 & 0.159 \\
\hline $\mathrm{T} 3=\mathrm{T} 2$ & 0.452 & 0.982 & 0.0828 & 0.617 & 0.961 & 0.761 & 0.304 \\
\hline $\mathrm{T} 3=\mathrm{T} 1$ & 0.376 & 0.574 & 0.153 & 0.529 & 0.345 & 0.365 & 0.912 \\
\hline $\mathrm{T} 2$ = T1 & 0.916 & 0.572 & 0.637 & 0.947 & 0.351 & 0.570 & 0.270 \\
\hline Observations & 658 & 659 & 636 & 629 & 630 & 632 & 630 \\
\hline R-squared & 0.085 & 0.078 & 0.066 & 0.089 & 0.074 & 0.050 & 0.048 \\
\hline Control group mean & 0.267 & 0.185 & 0.0936 & 0.0292 & 0.0345 & 0.0114 & 0 \\
\hline
\end{tabular}

Notes: Robust standard errors in brackets. Sample is migrants who completed the endline survey. All regressions include stratification cell fixed effects for survey group. Dependent variables are from the endline survey.

*** $\mathrm{p}<0.01, * * \mathrm{p}<0.05, * \mathrm{p}<0.1$ 
Appendix Table A1: Impact of treatments on remittances sent: Inverse hyperbolic sine transformation, transaction data in end-line sample

\begin{tabular}{|c|c|c|c|c|c|}
\hline & \multirow{2}{*}{\multicolumn{5}{|c|}{ 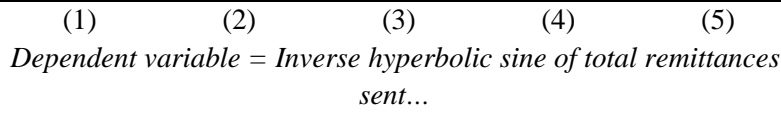 }} \\
\hline & & & & & \\
\hline & $\begin{array}{c}\text { During } \\
\text { discount } \\
\text { period }\end{array}$ & $\begin{array}{l}1 \text {-10 weeks } \\
\text { after }\end{array}$ & $\begin{array}{c}11-20 \\
\text { weeks after }\end{array}$ & $\begin{array}{c}21 \text {-30 } \\
\text { weeks after }\end{array}$ & $\begin{array}{c}31-40 \\
\text { weeks after }\end{array}$ \\
\hline \multicolumn{6}{|l|}{ Panel 1: All recipients } \\
\hline T4: Discount + information & $\begin{array}{c}0.450 \\
{[0.279]}\end{array}$ & $\begin{array}{c}0.338 \\
{[0.312]}\end{array}$ & $\begin{array}{l}0.675^{* *} \\
{[0.339]}\end{array}$ & $\begin{array}{c}0.237 \\
{[0.357]}\end{array}$ & $\begin{array}{c}0.142 \\
{[0.355]}\end{array}$ \\
\hline T3: Discount only & $\begin{array}{c}0.246 \\
{[0.311]}\end{array}$ & $\begin{array}{l}-0.0757 \\
{[0.330]}\end{array}$ & $\begin{array}{c}0.546 \\
{[0.342]}\end{array}$ & $\begin{array}{c}0.445 \\
{[0.362]}\end{array}$ & $\begin{array}{c}0.446 \\
{[0.378]}\end{array}$ \\
\hline T2: Information only & $\begin{array}{c}0.330 \\
{[0.286]}\end{array}$ & $\begin{array}{c}0.143 \\
{[0.315]}\end{array}$ & $\begin{array}{c}0.261 \\
{[0.350]}\end{array}$ & $\begin{array}{c}0.114 \\
{[0.367]}\end{array}$ & $\begin{array}{c}0.267 \\
{[0.350]}\end{array}$ \\
\hline \multicolumn{6}{|l|}{$P$-values for tests of coefficients } \\
\hline T4 \& T3 jointly equal to zero & 0.272 & 0.379 & 0.113 & 0.469 & 0.494 \\
\hline $\mathrm{T} 4=\mathrm{T} 3$ & 0.486 & 0.201 & 0.696 & 0.568 & 0.427 \\
\hline $\mathrm{T} 4=\mathrm{T} 2$ & 0.658 & 0.529 & 0.220 & 0.739 & 0.726 \\
\hline $\mathrm{T} 2=\mathrm{T} 3$ & 0.778 & 0.511 & 0.404 & 0.374 & 0.637 \\
\hline Observations & 665 & 665 & 665 & 665 & 665 \\
\hline R-squared & 0.126 & 0.176 & 0.143 & 0.132 & 0.150 \\
\hline Control group mean & 6.202 & 5.779 & 5.249 & 5.076 & 4.719 \\
\hline \multicolumn{6}{|c|}{ Panel 2: All transactions to PRR } \\
\hline T4: Discount + information & $\begin{array}{c}0.441 \\
{[0.353]}\end{array}$ & $\begin{array}{l}0.808^{* *} \\
{[0.374]}\end{array}$ & $\begin{array}{c}0.637 \\
{[0.392]}\end{array}$ & $\begin{array}{c}0.689 * \\
{[0.377]}\end{array}$ & $\begin{array}{c}0.237 \\
{[0.376]}\end{array}$ \\
\hline T3: Discount only & $\begin{array}{c}0.305 \\
{[0.374]}\end{array}$ & $\begin{array}{c}0.301 \\
{[0.386]}\end{array}$ & $\begin{array}{c}0.995^{* * * *} \\
{[0.379]}\end{array}$ & $\begin{array}{c}0.840 * * \\
{[0.379]}\end{array}$ & $\begin{array}{c}0.732 * \\
{[0.393]}\end{array}$ \\
\hline T2: Information only & $\begin{array}{c}-0.00888 \\
{[0.360]}\end{array}$ & $\begin{array}{c}0.153 \\
{[0.375]}\end{array}$ & $\begin{array}{c}0.0440 \\
{[0.376]}\end{array}$ & $\begin{array}{c}0.0884 \\
{[0.374]}\end{array}$ & $\begin{array}{c}0.341 \\
{[0.364]}\end{array}$ \\
\hline \multicolumn{6}{|l|}{$P$-values for tests of coefficients } \\
\hline T4 \& T3 jointly equal to zero & 0.444 & 0.0898 & 0.0301 & 0.0581 & 0.171 \\
\hline $\mathrm{T} 4=\mathrm{T} 3$ & 0.717 & 0.171 & 0.361 & 0.700 & 0.212 \\
\hline $\mathrm{T} 4=\mathrm{T} 2$ & 0.217 & 0.0729 & 0.130 & 0.119 & 0.778 \\
\hline $\mathrm{T} 2=\mathrm{T} 3$ & 0.409 & 0.693 & 0.0123 & 0.0516 & 0.313 \\
\hline Observations & 665 & 665 & 665 & 665 & 665 \\
\hline R-squared & 0.093 & 0.144 & 0.111 & 0.160 & 0.124 \\
\hline Control group mean & 4.772 & 4.016 & 3.625 & 3.346 & 3.121 \\
\hline \multicolumn{6}{|c|}{ Panel 3: All transactions to other recipients } \\
\hline T4: Discount + information & $\begin{array}{c}-0.108 \\
{[0.360]}\end{array}$ & $\begin{array}{c}-0.212 \\
{[0.369]}\end{array}$ & $\begin{array}{c}0.0848 \\
{[0.383]}\end{array}$ & $\begin{array}{l}-0.0319 \\
{[0.367]}\end{array}$ & $\begin{array}{c}0.0593 \\
{[0.356]}\end{array}$ \\
\hline T3: Discount only & $\begin{array}{c}-0.247 \\
{[0.379]}\end{array}$ & $\begin{array}{c}-0.670^{*} \\
{[0.385]}\end{array}$ & $\begin{array}{c}-0.221 \\
{[0.387]}\end{array}$ & $\begin{array}{c}-0.248 \\
{[0.383]}\end{array}$ & $\begin{array}{c}0.0421 \\
{[0.385]}\end{array}$ \\
\hline T2: Information only & $\begin{array}{c}0.278 \\
{[0.361]}\end{array}$ & $\begin{array}{c}0.450 \\
{[0.366]}\end{array}$ & $\begin{array}{c}0.347 \\
{[0.378]}\end{array}$ & $\begin{array}{c}0.131 \\
{[0.377]}\end{array}$ & $\begin{array}{c}0.114 \\
{[0.368]}\end{array}$ \\
\hline \multicolumn{6}{|l|}{$P$-values for tests of coefficients } \\
\hline T4 \& T3 jointly equal to zero & 0.808 & 0.214 & 0.734 & 0.785 & 0.986 \\
\hline $\mathrm{T} 4=\mathrm{T} 3$ & 0.719 & 0.247 & 0.447 & 0.573 & 0.964 \\
\hline $\mathrm{T} 4=\mathrm{T} 2$ & 0.295 & 0.0814 & 0.503 & 0.667 & 0.883 \\
\hline $\mathrm{T} 2=\mathrm{T} 3$ & 0.175 & 0.00485 & 0.152 & 0.336 & 0.856 \\
\hline Observations & 665 & 665 & 665 & 665 & 665 \\
\hline R-squared & 0.094 & 0.111 & 0.063 & 0.067 & 0.065 \\
\hline Control group mean & 3.933 & 3.700 & 3.267 & 3.394 & 3.036 \\
\hline
\end{tabular}


Appendix Table A2: Baseline balance - Endline sample

\begin{tabular}{|c|c|c|c|c|c|c|c|c|c|}
\hline & \multirow[b]{2}{*}{ T0: Control } & \multicolumn{2}{|c|}{ Means } & \multirow[b]{2}{*}{$\begin{array}{c}\text { T3: } \\
\text { Discounts }\end{array}$} & \multicolumn{3}{|c|}{ P-values } & \multirow[b]{2}{*}{$\mathrm{T} 0=\mathrm{T} 3$} & \multirow[b]{2}{*}{$N$} \\
\hline & & $\begin{array}{c}\mathrm{T} 1: \\
\text { Information }\end{array}$ & $\begin{array}{l}\text { T2: Info \& } \\
\text { Discounts }\end{array}$ & & $\begin{array}{c}\mathrm{T} 0=\mathrm{T} 1= \\
\mathrm{T} 2=\mathrm{T} 3\end{array}$ & $\mathrm{~T} 0=\mathrm{T} 1$ & $\mathrm{~T} 0=\mathrm{T} 2$ & & \\
\hline Migrant is female & 0.28 & 0.33 & 0.23 & 0.29 & 0.217 & 0.284 & 0.277 & 0.826 & 665 \\
\hline Migrant age & 34.3 & 34.4 & 34.8 & 33.9 & 0.877 & 0.985 & 0.661 & 0.679 & 645 \\
\hline Migrant is from Guatemala & 0.72 & 0.79 & 0.79 & 0.76 & 0.389 & 0.150 & 0.126 & 0.345 & 653 \\
\hline Migrant years in US & 9.5 & 8.7 & 9.5 & 9.4 & 0.475 & 0.187 & 0.917 & 0.859 & 655 \\
\hline Migrant is married & 0.52 & 0.60 & 0.64 & 0.63 & 0.099 & 0.146 & 0.032 & 0.031 & 665 \\
\hline Migrant's spouse lives in the US & 0.54 & 0.55 & 0.47 & 0.55 & 0.651 & 0.863 & 0.377 & 0.825 & 383 \\
\hline Migrant number of children & 2.0 & 2.2 & 2.1 & 2.2 & 0.659 & 0.247 & 0.485 & 0.315 & 665 \\
\hline PRR is female & 0.74 & 0.80 & 0.79 & 0.80 & 0.425 & 0.154 & 0.256 & 0.159 & 663 \\
\hline Migrant remittances as percent of income & 34.1 & 36.2 & 36.6 & 35.8 & 0.609 & 0.289 & 0.222 & 0.388 & 601 \\
\hline Migrant annual remittance to PRR (\$) (survey reported) & 5,836 & 6,252 & 6,156 & 6,276 & 0.872 & 0.486 & 0.603 & 0.459 & 661 \\
\hline Mirgrant annual remittance to other hhs (\$) (survey reported) & 860 & 802 & 840 & 1,396 & 0.038 & 0.806 & 0.935 & 0.021 & 651 \\
\hline Migrant number of recipient households & 1.6 & 1.6 & 1.7 & 1.8 & 0.117 & 0.661 & 0.067 & 0.047 & 648 \\
\hline Number of transactions to PRR: Viamericas & 17.7 & 17.6 & 18.3 & 17.1 & 0.834 & 0.928 & 0.655 & 0.615 & 659 \\
\hline Number of transactions to PRR: Other channels & 0.9 & 1.1 & 0.8 & 0.8 & 0.603 & 0.450 & 0.681 & 0.635 & 659 \\
\hline Number of transactions to other recipients: Viamericas & 1.3 & 1.9 & 1.8 & 2.9 & 0.171 & 0.405 & 0.502 & 0.028 & 443 \\
\hline Number of transactions to other recipients: Other channels & 0.2 & 0.3 & 0.3 & 0.2 & 0.880 & 0.608 & 0.432 & 0.786 & 444 \\
\hline \multicolumn{10}{|l|}{ Migrant's highest level of education is... } \\
\hline ...none & 0.30 & 0.37 & 0.30 & 0.36 & 0.368 & 0.159 & 0.970 & 0.243 & 665 \\
\hline ...primary & 0.29 & 0.25 & 0.21 & 0.21 & 0.200 & 0.416 & 0.072 & 0.069 & 665 \\
\hline ...secondary & 0.07 & 0.08 & 0.11 & 0.07 & 0.576 & 0.700 & 0.195 & 0.892 & 665 \\
\hline ...university & 0.03 & 0.02 & 0.03 & 0.02 & 0.938 & 0.591 & 0.696 & 0.573 & 665 \\
\hline \multicolumn{10}{|l|}{ Primary recipient is migrant's... } \\
\hline ...parent & 0.44 & 0.37 & 0.35 & 0.38 & 0.426 & 0.236 & 0.116 & 0.275 & 665 \\
\hline ...spouse & 0.21 & 0.21 & 0.30 & 0.24 & 0.174 & 0.975 & 0.051 & 0.508 & 665 \\
\hline ...sibling & 0.13 & 0.13 & 0.17 & 0.15 & 0.721 & 0.968 & 0.332 & 0.604 & 665 \\
\hline ...child & 0.07 & 0.08 & 0.04 & 0.08 & 0.483 & 0.834 & 0.237 & 0.873 & 665 \\
\hline \multicolumn{10}{|l|}{ Transaction data - previous 365 days } \\
\hline All - total transactions & 16.7 & 18.7 & 16.6 & 16.2 & 0.407 & 0.212 & 0.931 & 0.740 & 665 \\
\hline All - total amount (\$) & 5,401 & 5,584 & 4,945 & 5,098 & 0.608 & 0.717 & 0.380 & 0.548 & 665 \\
\hline All - mean transaction amount (\$) & 370 & 343 & 344 & 355 & 0.855 & 0.439 & 0.465 & 0.662 & 663 \\
\hline PRR - total transactions & 9.5 & 9.6 & 9.5 & 9.5 & 1.000 & 0.919 & 0.978 & 0.992 & 665 \\
\hline PRR - total amount (\$) & 3,113 & 3,014 & 3,212 & 3,206 & 0.962 & 0.810 & 0.816 & 0.821 & 665 \\
\hline PRR - mean transaction amount (\$) & 341 & 329 & 372 & 354 & 0.746 & 0.753 & 0.445 & 0.736 & 658 \\
\hline Others - total transactions & 7.2 & 9.1 & 7.1 & 6.7 & 0.122 & 0.080 & 0.876 & 0.629 & 665 \\
\hline Others - total amount (\$) & 2,287 & 2,570 & 1,734 & 1,892 & 0.053 & 0.384 & 0.096 & 0.221 & 665 \\
\hline Others - mean transaction amount (\$) & 390 & 324 & 316 & 330 & 0.407 & 0.176 & 0.135 & 0.213 & 534 \\
\hline
\end{tabular}

Notes: Sample is migrants recuited at baseline who completed endline survey. Data comes from baseline survey and Viamericas transaction data. Sample varies slightly with missing

values. P-values come from regressions of each baseline variable on the treatment variables, including stratification cell fixed effects for survey group. 